Portland State University

PDXScholar

$1-1-2011$

\title{
From Blooming Judicial Philosophies to Castrated Legislation: Sexuality, Desire, and Nominations to the Supreme Court of the United States
}

Adam Michael McMahon

Portland State University

Follow this and additional works at: https://pdxscholar.library.pdx.edu/open_access_etds Let us know how access to this document benefits you.

\section{Recommended Citation}

McMahon, Adam Michael, "From Blooming Judicial Philosophies to Castrated Legislation: Sexuality, Desire, and Nominations to the Supreme Court of the United States" (2011). Dissertations and Theses. Paper 288.

https://doi.org/10.15760/etd.288

This Thesis is brought to you for free and open access. It has been accepted for inclusion in Dissertations and Theses by an authorized administrator of PDXScholar. Please contact us if we can make this document more accessible: pdxscholar@pdx.edu. 
From Blooming Judicial Philosophies to Castrated Legislation: Sexuality, Desire, and Nominations to the Supreme Court of the United States

by

Adam Michael McMahon

A thesis submitted in partial fulfillment of the requirements for the degree of

\author{
Master of Science \\ in \\ Political Science
}

Thesis Committee:

Christopher Shortell, Chair

Richard Clucas

Bruce Gilley

Portland State University

(C)2011 


\begin{abstract}
Society and institutions of government reinforce norms that constrain the behavior of individuals. Heteropatriarchal norms traditionally favor the perspective of white, male, heterosexual, reason, judicial restraint, and democratic authority over their binary, and minority, counterparts: black, female, homosexual, desire, judicial activism, and individual rights. According to the theory of Queer New Institutionalism, these dichotomous pairs are mutually dependent upon each other for definition and maintenance. The perpetuation of these binarisms is made through language, often assumed and unquestioned. However, the use of sexualized language and metaphors are identified in efforts to draw suspicion and consternation for these minoritized Others. When the presence of an Other is missing, those that would reinforce these norms being to skirt the line between the pairings, taking the position of the individual they would otherwise criticize. By utilizing critical discourse analysis, Supreme Court nomination hearings during the $109^{\text {th }}$ and $111^{\text {th }}$ Congresses were reviewed for support for the theory of Queer New Institutionalism. Senators and witnesses before the committee operated within the constraints of binary thinking and instances of sexualized and gendered language, as well as metaphors, were used to perpetuate these norms and link the nominees to the suspicion surrounding Others.
\end{abstract}


Dedication

For my sister, Katie. 


\title{
Table of Contents
}

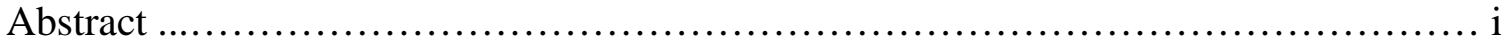

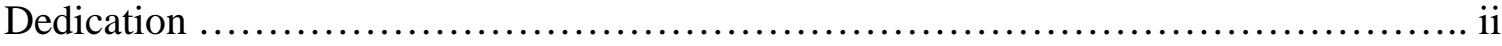

Chapter 1

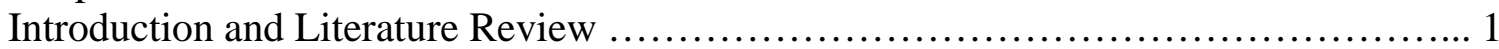

Chapter 2

Methods and Judicial Nominations during the $109^{\text {th }}$ United States Congress ............ 28

Chapter 3

Supreme Court Nominations during the $111^{\text {th }}$ United States Congress ................. 52

Chapter 4

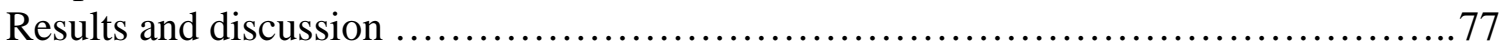

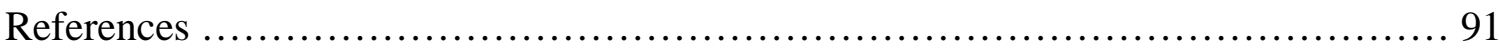

Appendices
A. Controversial Roberts Photo
B. Controversial Kagan Photo
97
C. Internet Search Results 


\section{Introduction \& Literature Review}

If one were to pay attention to Supreme Court nomination hearings before the United States Senate Committee on the Judiciary, they would be inclined to notice that among the discussions regarding prior and potential cases, conversations about stare decisis, and emphasis on judicial qualifications, a large portion of the debate contains the underlying theme concerning judicial activism versus judicial restraint. On the one hand, activism is associated with all potential negative things that could come from a Supreme Court justice: overturning precedent, making decisions based on personal policy preferences, and ignoring the Constitution (Kagan 2010, Day 1, 446:00; U.S. Senate 2009, 35). On the other, restraint represents the ideal position which it is hoped that all potential justices will anchor themselves: fidelity to the law, narrow decision-making, and respect for precedent and the Constitution (Kagan 2010, Day 1, 443:00; U.S. Senate 2009, 59, 79; Wechsler 1959, 19).

This study will review the confirmation hearings of Supreme Court nominees during the $109^{\text {th }}$ and $111^{\text {th }}$ Congresses and examine language for support for institutionalized normative behavior. Instances of gendered and sexualized language, as well as the use of metaphors, will be identified to show the power Senators exert to reinforce expected and assumed norms on the part of nominees. Even though judicial activism/judicial restraint is the most prevalent binary pair exhibited throughout the nomination proceedings, a number of pairings exist and function to reinforce expected behaviors: male/female, white/black, heterosexual/homosexual, reason/desire, democratic authority/individual rights. These binary pairs are linked by underlying assumptions 
regarding sexuality and desire (Burgess 1999, 203, 213). Identifying language during nomination hearings that maintains thinking within these dichotomous terms will show how normative behavior, and expectations of it, influence politics on a practical level.

However, upon closer inspection, the relative incoherence of the term "judicial activism” eventually arises. It is applied to both conservative and liberal justices, from Democratic and Republican senators alike. This illustrates the predicament the debate encounters when it is limited by the construction of dichotomous terms judicial restraint and judicial activism. This pairing, or binarism, is one among many that constrains government and its institutions. It represents an asymmetrical power relationship, with each term mutually dependent on the other to define itself. The reinforcement of binarisms perpetuates the status quo, favoring traditional heteropatriarchal values (Butler 1990, 3, 31, 39; Sedgwick 10-11; Burgess 1999, 202-207).

\section{Problem}

The use of dichotomous pairs in characterizing the behavior of Supreme Court justices is constraining and obscures the debate, eliminating consideration of any alternatives that are outside of such binarisms (Burgess 1999, 201, 213; Gibson and Caldeira 2009, 143). Such categorizations assume that there is an objective approach to interpreting the United States Constitution, and judicial restraint is assumed to be the default position, dominant to its lesser alternative, judicial activism (Burgess 1999, 200201, 205). This is similar to arguments furthered by queer theorists, as well as feminists and critical race theorists, by examining and deconstructing a wide variety of relationships to understand their underlying assumptions and the power exchange 
between the categorizations assumed to be natural (Burgess 1999, 201; Jagose 1996, 1618; Butler 1990, 3, 31, 46).

An examination of Supreme Court nomination hearings before the Senate Judiciary Committee utilizing the theory of Queer New Institutionalism allows for a critical examination of the heterosexist construction that serves as a basis for our social institutions (Jagose 1996, 17). It takes key elements from queer theory, arguing that the theoretical categorizations established and perpetuated in society, such as strict gender roles, are deficient and cease to function properly when practically applied (Burgess 1999, 213). Likewise, a New Institutionalist perspective takes into account attitudes, norms, influences, etc., that might also influence what occurs in regards to the nomination hearings (Gillman \& Clayton 1999, 4). Therefore, a Queer New Institutionalist perspective in analyzing recent Supreme Court nomination hearings will allow for a critical examination by deconstructing the conversation between senators and nominees. The underlying assumptions can be revealed, illuminating how they influence and impact the direction of the hearings.

\section{Questions}

This study will attempt to answer the following research questions:

What are the underlying sexual themes that permeate nomination hearings for judges and justices before the Senate Judiciary Committee?

How are the heterosexist norms that are present in discussions regarding constitutional theory reinforced through nomination hearings?

What is the effect of the persistence of institutionalized heterosexist norms? 
As queer theorists charge, theoretical categorizations of gender will ultimately break down when applied in practice. This is due to the inevitable arising of individuals that prove to be exceptions to the rule and cannot be easily classified by the strict constructions of male or female (among other dichotomous pairings) (Butler 1990, 39; Burgess 1999, 213). Likewise, following a Queer New Institutionalist perspective, one could hypothesize that categorizations into judicial activism versus judicial restraint would be faulty in practice, as individuals and situations could arise where the strict categories do not hold. Failings in practice might not preclude the influence that the theoretical categorizations have upon practical matters. Supreme Court nomination hearings are a prime environment for the debate regarding judicial activism versus restraint, and along with all the other constraining dichotomous pairings can be questioned and investigated.

\section{Heteropatriachal norms and the persistence of sexism}

Society is constructed and reliant upon assumptions regarding how it is and should be ordered. The family serves as the basis for this, with heterosexual marriages constituting the bases for these units. They are traditionally dominated by men and are perpetuated through replication over time. Burgess argues that this arrangement is assumed to be natural, given, and universal (Burgess 1999, 203). It serves as the basis for society, the nation, and onwards.

In an article titled "Sexism in Naming the World: Consciousness in a Patriarchal Iceberg,” authors Martel and Peterat (1984) argue that patriarchal structures of power are so preeminent in our world, that they are barely noticed. This is also reflected in 
language, where men also maintain privilege. For example, words frequently used to describe women have negative connotations, such as chick, witch, bitch, etc. and are abundant in language (46-47). Their argument is that this acceptance of power structures and connotations assigned different roles for men and women reinforce a subtle legitimization of the existing power structures. Our language containing these sexist terms helps to enable patriarchal structures (Martel and Peterat 1984, 48).

Martel and Peterat's article convincingly makes the case that patriarchal assumptions in language dominate. Not only do they serve to reinforce the assumed subservient position of women, but those of blacks as well. Language connects persisting ideas about religion and myths with personal practices and beliefs:

\footnotetext{
"Just like the slave who confesses to being 'no good' because she or he has learned to gauge personal worth according to the master's (seldom mistress') definition of a 'good slave', we use a language which constantly judges our second rate worth - or worthlessness.” (Martel and Peterat 1984, 49)
}

The emergence of queer theory has given impetus for changing the questions asked in regards to gender and studies of sexuality. As McElhinny (2002) argues in her article, "Language, Sexuality and Political Economy," instead of asking what gender differences exist between genders, focus should shift to answer what difference gender makes. She argues that the construction of society into dual roles, such as male and female, white and black, or even rational and irrational, are constructed in order to exclude other identities. These "Others" are seen as being unfavorable in the dominant conception of society, or even unimaginable (14). Similar to explanations given by queer new institutionalism, certain gendered behaviors become policies as revealed in McElhinny's article. Language reflects beliefs, and these beliefs become actions that are 
reinforced. The dominant forces in society reinforce the positions of white males, and they are associated by gender to be rational and objective. This is opposed to the irrational and subjective which is associated with the feminine, as McElhinny notes. In which case, the dichotomy between judicial restraint and activism, anything other than the traditional vision of the ideal judge, becomes associated with the identity of those officials that are female, black, LGBT, etc. It reinforces the excluded identities as Others (McElhinny 2002, 114).

The author describes heteronormativity, which is what has come to be expected from both genders. These values are analyzed to see how they impact LGBT persons, but the author rejects constraints based on these values. Instead, she calls for an understanding of sexuality that is stratified along a spectrum. The problem raised by McElhinny that needs further understanding is that "sexuality is still rarely understood as embedded in institutions and relations of inequality” (McElhinny 2002, 118-119). Moving towards a stratified understanding of sexuality, as well as gender, would work towards removing stereotypes regarding the roles of different individuals based on sex, gender, race, and sexual orientation. As the article notes, most people do not work in environments that are entirely welcoming and embracing of queer persons. For example, it is noted that women that assume occupations traditionally associated with men are often assumed to be lesbian. This label is still used as a pejorative term and is meant to insult (McElhinny 2002, 121-122).

According to King (1991), men and women approach language in distinct ways, and the dominant theories as to why this is are the "difference approach," where men and 
women are believed to be from different subcultures, and the “dominance approach,” where men are believed to reinforce their role in our patriarchal society. This is reflected in conversations between men and women (King 1991, 2).

Sexism exists if men and women are treated differently, if the treatment is less favorable to women, and if the basis for this treatment is attributed to gender. When it comes to sexist language, that which is associated with maleness is deemed normal, or there will be irrelevant reference to gender or physical appearance in domestic relationships. Sexism persists in how women are addressed, or if they are addressed at all -women are often ignored or objectified (King 1991, 3).

Historically, strong women have been ascribed adjectives that have decidedly negative connotations that otherwise would not be used towards their male counterparts. Studies have shown that sexualized language also reinforced the subordinate role of women and embraces negative stereotypes. By one estimate, there are 220 sexualized terms for women and only 22 for men. Researchers ascribe this to patriarchal dominance in language, such as men being the ones who write the dictionary (King 1991, 22-23).

Sexism and racism exist because of more than just language, but using language that reflects inequalities not only perpetuates existing differences in power, but reinforces existing social structures (King 1991, 72). Conversely, according to King, removing gender from all terms might suggest hypersensitivity (the book notes that a style guide in Canada says it would be unusual to replace the term "man eating tiger” with "person eating tiger”). The author instead argues for the usage of similar terminology regardless of sex in order to suggest the lack of sexist attitudes (King 1991, 76-78). 
Queer theory and Queer New Institutionalism

In order to understand the constraints formed by the application of heteropatriachal assumptions, one could start with Sedgwick's Epistomology of the Closet (1990) and Butler's Gender Trouble (1990), seminal works in the establishment of queer theory. The authors challenged the asymmetrical power balances that constituted relationships and served as the basis for the order of institutions and society. Segdwick argues that all of Western culture is based upon the structure of the hetero versus homosexual axiom. She attributes the instability of these constructions to the inherent paradox embedded within them. There is the minoritizing view, that homosexuals comprise a small subset within a gender, and the universalizing view, that sexuality exists on a spectrum and homosexuals operate as the transitive gender between male and female. These two views are mutually exclusive and invariably lead to conflict (Sedgwick 1990, 1-2).

Defining homosexuality gave the term an identity, offset by what is perceived to be the more prevalent heterosexual. This created the power imbalance, where the heterosexual is assumed to be natural, but then begins to rely on the homosexual for definition. Without the homosexual, there is no heterosexual. The terms heterosexual/homosexual then cease to be associated with sex acts and, instead, being to comprise and entire identity defined by the terms (Sedgwick 1990, 10). According to Sedgwick, what is not said has just as much significance as what is said. She argues that which involves the closet can be especially revealing (Sedgwick 1990, 3). Her goal in pursuing a queer theory was not to wade into the essentialist versus constructivist debate 
regarding homosexuality, but to open "the extent, construction, and meaning, and especially the history of any such theoretical continuity - not to mention its consequences for practical politics - must be open to every interrogation” (Sedgwick 1990,39). By challenging the unspoken, assumed, and inherent, especially in how they relate to the distribution of power, much can be revealed about how constraints of binarisms shape reality.

In Gender Trouble (1990), Butler claims that individuals are formed and crafted in accordance with political and social structures in society (Butler 1990, 3). She argues that gender and sex should be distinct. These categories exists in what she calls a "prediscursive domain" and when you remove them from their binary structures, such as male versus female and masculine versus feminine, they become "free-floating" (Butler 1990, 9-13). Understanding gender and sex in this way is important because it allows one to see femininity as defined as being the Other with masculinity being "synonymous with the “universal”' (Butler 1990, 25).

Butler states that the binary relationship between the two established sexes is regulated by grammar. It assures that nothing outside the dichotomous relationship can be sustained. The problem, she establishes, is that this construction is doomed to failure. Exceptions to the two established categories will inevitably arise. The construction of these sexes, deemed to be natural, will unravel in the face of an Other that challenges assumptions about the categorizations of gender and sex (Butler 1990, 26-46).

Understanding the instability and conflict in attempting to categorize heterosexuality and homosexuality helps in approaching other dichotomous pairs. 
Binarisms identified by queer theory, such as male/female, white/black, rational/irrational, reason/desire and even judicial restraint/judicial activism. The minoritizing versus universalizing (or transitivity and separatism) paradox involving the heterosexual/homosexual mirrors the conflict inherent in constitutional theory between so-called judicial restraint/judicial activism.

Burgess (1999) argues that, in regards to constitutional theory, judicial restraint holds the dominant position. She argues that even though there is no objective approach as to how to interpret the constitution, judicial restraint has default legitimacy. Without an objective position to conduct judicial review, unelected judges are given the power and authority to invalidate what is enacted into law by democratically elected representatives. Therefore restraint becomes the dominant perspective because it accepts the preeminent role of “democratic authority.” This is in contrast to judicial activism, although also subjective, is seen as being “anti-democratic.” It represents a judge’s pursuit of their own political desires and the rejection of reason (Burgess 1999, 205).

Burgess employs what she calls a Queer New Institutionalism, in order to challenge the assumptions regarding binarisms identified by queer theory. She links judicial restraint/activism, as well as a host of other binarisms, to underlying sexuality and desire that goes unquestioned in society. Burgess argues that it expressed by sexualized language within the debate of constitutional theory. Although it goes without notice, she cites several books containing terms frequently used and have a sexualized connotation. For example, Robert Bork’s The Tempting of America: The Political Seduction of the Law (1990) and Slouching Towards Gomorrah: Modern Liberalism and 
American Decline (1996), and Carl Cohen's Naked Racial Preference: The Case Against Affirmative Action (1995). She argues for a more critical analysis of the underlying sexual assumptions that serve as the unquestioned basis for much of the discussion between advocates of judicial restraint versus those favoring judicial activism in consideration of the U.S. Constitution (Burgess 1999, 207-208).

A specific investigation by Burgess into Herbert Wechsler’s description of “naked power organs” in “Toward Neutral Principles of Constitutional Law” (1959) is employed to further link judicial restraint/judicial activism to sexuality and desire. In it, Wechsler appeals for a Supreme Court that “clothes” itself in "neutral principles” in being objective in ruling on the law. This is in contrast to judicial activism, which represents the pursuit of desired personal policy preferences. When justices allow the Court to be used in this way, they are acting as a "naked power organ.” This instance of explicitly sexualized language reveals his adherence to the confines of reinforced binarisms. An activist Supreme Court is one that pursues its desires and passions in trying to craft the law. It goes against reason. It is like a pervert who flashes his privates and has no shame, i.e. the homosexual. In his call for neutrality and objectivity in consideration of constitutional questions, Wechsler “outted” himself as being within the constraints of the dichotomous relationships that define our system: heterosexuality as opposed to homosexuality, male as opposed to female, and judicial restraint as opposed to judicial activism. His words defined his reality, and as Burgess explains, this reality helped define him as an individual (Burgess 1999, 210-213). 
New Institutionalist approaches call for an understanding of how actors operate within and under the influence of institutions, as well as social and political factors. Research approaching judges from the New Institutional view consider the social context in which rulings are made, as well as the norms that courts must abide by so that their rulings are seen as being legitimate. They must be aware of outside factors if they expect their judicial opinions to have grounding, justification, to be accepted by the public at large. Therefore, New Institutionalist approaches are able to transcend the barrier between empirical analysis and the norms that constrain courts. They serve to describe these influences as well as critique their impact (Gillman and Clayton 1999, 2-5).

With similarities between queer theory and New Institutionalism, Burgess (1999) calls for using Queer New Institutionalism as a new approach in considering the Constitution. She argues that since there is no consensus on how to interpret the Constitution, problems will persist in consideration of constitutional theory. Calling for a New Queer Institutionalist approach, she offers a critique of how society reinforces “heterosexist constructions of sexuality” (Burgess 1999, 199-200). Burgess rejects the focus given on the preferences of choices made by judges as explained by rational choice theory. This shallow analysis fails to explain how judges come to decisions within the context of the society and institutions within which they operate. Conversely, she charges that New Institutionalism ignores heteronormative concepts that dominate our system of governance (Burgess 1999, 203).

The role of the Senate Judiciary Committee 
According to Article II, Section 2, Clause 2 of the US Constitution states that the president is to appoint judges to the Supreme Court and other officers of government with the "advice and consent" of the Senate. The bulk of this work transpires in the Senate Judiciary Committee, with the full Senate voting on to confirm the president's recommendations after they are referred from the committee (Schuck 1975, 224).

Congress decides on the number of courts and judges that exist and the number of nominations submitted for review by the Senate varies per session. Reviewing these nominations takes a significant portion of the committee's time. The nominations of Supreme Court justices, circuit court of appeals judges, and district court judges are considered by the committee (Schuck 1975, 223). Investigations into Supreme Court nominees are highly visible (O’Brien 2009, 106).

Gibson and Caldeira (2009) speculate that Americans form opinions about Supreme Court nominees based on two possible considerations: if the individual nominated has the qualifications and the experience to be a judge and if their ideology is within the mainstream. They suggest that partisan ideology might come into play if nonpartisan experience and qualifications are not clear (Gibson and Caldeira 2009, 140). Debates regarding a nominees judicial qualifications, the following of stare decisis, or arguments based on policy and political ideology are often complicated by charges of “judicial activism” (Gibson and Caldeira 2009, 143).

The authors then claim that in order for a Supreme Court nominee to be successful, they must focus on their judicial qualifications instead of political themes, and such was the case of Samuel Alito. Those that support a nominee will emphasize the 
judicial qualifications, while those opposed will focus on controversies derived from political and policy related perspectives (Gibson and Caldeira 2009, 140, 144). If opposition to a nominee is to be successful, they have to focus on the political, policy, and ideological issues necessary to derail confirmation, however Gibson and Caldeira argue that this would be extremely difficult if there is even a modicum of support for the argument that the nominee is judiciously qualified to serve on the Court given the "reservoir of goodwill” that the Supreme Court maintains with the public (Gibson and Caldeira 2009, 153).

Gibson and Caldeira believe that those that have preexisting institutional loyalty to the Supreme Court are more likely to evaluate a nominee to the Supreme Court based on their judicial qualifications compared to someone with less institutional loyalty, who would then be more likely to judge the nominee based on political considerations (Gibson and Caldeira 2009, 151). Their survey research found that frames are important in helping citizens to evaluate nominees based on criteria involving judiciousness, which is the necessary area of focus for the nominee and supports if they wish to secure confirmation (Gibson and Caldeira 2009, 153).

The Senate Judiciary Committee hearings for nominees serve as a forum where the discussion of judicial restraint versus activism persists. Judicial restraint is the dominant theme persistent in many nomination hearings and is often associated with originalists and strict constructionists. They acknowledge the persistence of this dialogue in viewing the Constitution from a position of judicial restraint, whether they be 
originalists, strict constructionists, or textualists, are set in contrast to those that believe the Constitution is a living document (O’Brien 2009, 200). According to Justice Scalia,

"It is only in recent years... that non-originalist exegesis has, so to speak, come out of the closet, and put itself forward overtly as an intellectually legitimate device... If constitutional interpretation could be adjusted as changing circumstances required, a broad initial interpretation would have been unnecessary.” (O’Brien 2009, 198-199)

Scalia discusses originalism and contrasts it with what he calls "nonoriginalism.”

He successfully frames the debate within terms of a dichotomous relationship.

Originalism is a developed and visible interpretation that is contrasted by Scalia to all others. It thereby obscures other conceptions of the Constitution that might not fit within the confines of the spheres labeled “originalism” and "nonoriginalism.” Instead of being one among many ideas regarding the Constitution or perhaps one on a spectrum, it is presented as being one of two options: the right way versus everything else. Thus orignalists are able to own the concept of judicial restraint, while others can subsequently be characterized as judicial activists (O’Brien 2009, 200).

Sager (2004) refutes originalism and challenges Americans to ask why constitutional practices should be dictated by those long deceased and judges appointed and removed from popular elections. He instead insists that the Constitution is underenforced. He uses provisions to provide for minimum welfare and to combat socially entrenched biases as two prominent examples to support his position. He argues that it is a good thing that they are under enforced by the Supreme Court, because they should be enforced by policy developed from popularly elected officials (Sager 2004, 3-7). 
Sager makes an argument that the Constitution is least successful when it is the most restrictive, such as in the Seventh Amendment where juries are permitted for civil trials involving amounts over twenty dollars. Sager wants to know why some ideas, such as equal protection, are so broadly outlined by the Constitution, when the framers were evidently capable of being specific and particular in addressing certain aspects, such as in the Seventh Amendment (Sager 2004, 51-52).

Sager states that the framers did not have the opportunity that we have today: the ability to draw upon the experiences of generations of people living under the Constitution and observe its practical impact. The Constitution was crafted, debated, and ratified, but this was for the text guaranteeing, for example, equal protection, and not how that specific text would apply to a specific situation 100 years in the future (Sager 2004, 55-56). Sager categorizes constitutional practices into three categories: There is agency, which includes orignalism and reluctant judgment; partnership, including justice seeking approaches and democratarians; and guardianship approaches, which the author notes is not a viable approach thus far in American constitutionalism (Sager 2004, 16).

To reinforce his position, Sager details how high profile originalists, such as Justice Scalia and failed Supreme Court nominee Robert Bork, stray from their constitutional philosophies. This is in spite of the perpetuating argument that underlies Supreme Court nomination hearings: the debate between judicial restraint and judicial activism, between originalists and those that believe in a Living Constitution (Sager 2004, 58-59; O’Brien 2009, 207).

Left with only two viable approaches to the constitution, Sager admits that, 
“The reader may feel that I am forcing constitutional theory, and hence constitutional theorists, against an artificially sharp dichotomy between the agency model with its instruction-taking ideal and the partnership model with its collaborative ideal. It may appear that I have somehow lumbered reluctant judgment theory with conceptual entailments that it need not accept. But the point is this: Either we value the independent judgment of judges as collaborators in the constitutional project of identifying the fundamental demands of political justice or we do not.” (Sager 2004, 68-69)

Even as a critic of originalism and despite his ability to set forth a number of approaches to constitutional theory in the United States, Sager is able to construe his argument within the confines of a binarism. Although he notes that this construction into two spheres is “artificial,” it is beside the point and he goes on to highlight what he finds more instructive to those approaching the debate. However, when one confronts the conversations forwarded in nomination hearings before the Senate Judiciary Committee, one finds that these dichotomous approaches to constitutional theory are utilized, artificial or not.

A review of these interpretations regarding the Constitution shows that binarisms are effective in framing the debate. Reducing the debate to a choice between judicial restraint/judicial activism pushes out alternative conceptions, such as those identified by Sager. It allows justices, like Scalia, to cast his position within the mainstream of “restraint” and everything else that differs as "activist.” It demonstrates the effectiveness of these perpetuating normative constraints.

The Senate Judiciary Committee and Supreme Court nomination hearings are not strangers to controversies surrounded gender, race, and sexuality. In 1991, Professor Anita Hill alleged that the nominee, Judge Clarence Thomas, has sexually harassed her 
several years before. Professor Hill alleged that while she had worked as Judge Thomas' subordinate in the 1980s at the Equal Employment Opportunity Commission, he had sexually harassed her. These allegations, tantamount to a he-said she-said debate, were revealed just days before the committee was expected to vote on Thomas' confirmation when a staffer leaked the allegations to the media (Ragan et al. 1996, xv-xvi, 133). During the Hill-Thomas controversy, it may not have been the intent of the senators to treat Hill unfairly or unjustly, but the dynamic and power relationships revealed in language studies of the hearings prove otherwise (Ragan et al. 1996, xx). The members of the Senate Judiciary Committee are not impartial judges, but rather elected officials that serve six year terms. They are held accountable by the electorate. As a member of the committee, they may take on the role of an impartial judge, a juror deciding which testimony to believe, or a political actor pushing a certain agenda. Which of these roles they assume, explicitly or implicitly, is the decision of the individual senator (Ragan et al. 1996, 6-7).

Thomas, in now famous words, referred to his nomination hearing as a "high-tech lynching” and used the metaphor to illustrate the proceedings as being organized along racial lines, as opposed to Hill who did not evoke a similar metaphor while simultaneously defying stereotypes by being an educated, single, professional black female (Ragan et al. 1996, 53). Nevertheless, these words were a powerful from a black man facing a black female accuser before a panel of all white, male senators (Ragan et al. 1996, 39). As Hill herself stated, "because I and my reality did not comport with what 
they accepted as their reality, I and my reality had to be reconstructed by the Senate committee members with assistance from the press and others” (Ragan et al. 1996, 49).

Ragan et al. (1996) utilize a number of diverse studies in order to examine the Hill-Thomas controversy in ways that were not necessarily within the realm of public perception when the hearings actually took place. Notably among them, one chapter focuses on how individual senators were able to use their roles as questioners on the committee to reconstruct Clarence Thomas' image for the public. Before the accusations broke, Thomas' team focused on selling his trustworthiness to the committee and tried to avoid emphasis on controversial issues. For example, he evaded questions concerning abortion. However, the authors argued that this led to suspicion regarding his trustworthiness (Ragan et al. 1996, 91). The sexualized language attributed to Thomas did not have to be proved or disproven, because of the political setting, his supports only had to deflect attention away from controversy and mold him within the confines of what was expected from a potential Supreme Court justice to mainstream Americans.

From an intercultural examination of the Hill-Thomas hearings, one analysis from Ragan et al. (1996) attempts to show how outgroups versus ingroups set the stage for how the public viewed and interpreted the hearings. Hill was a woman and black standing before the senators who were all male and white (Ragan et al. 1996, 58). The idea of self is something that is socially constructed but evolved and constantly being refined. Most conceptions of the self revolve around dichotomous parings, such as public versus private, but also “while defying definition” (Ragan et al. 1996, 63). The Hill-Thomas hearings served as an example in the past where the Senate Judiciary Committee served 
as an arena where identity was crafted, but the accused and the accuser, in order to win public support.

After Anita Hill was forced to come forward with her claims of sexual harassment, it was the job of Republican senators to advocate on behalf of Thomas in order to repair his image to the public and save his nomination. Senator Specter reconstructed Hill’s narrative by repeating what she said and highlighting alleged inconsistencies. In his closing remarks he ignored her answers and reiterated her claims (Ragan et al. 1996, 50-51). Although the hearings were formatted in much the same way as a trial, they were not. Thomas was able to defend himself more effectively by speaking to the committee before his accuser addressed it. Senator Specter accused Hill of the crime of perjury through his line of questions directed at Thomas and inflecting his opinion to shift the criticism onto her (Ragan et al. 1996, 180-181). By defining Hill as the Other, a woman who defied heteronormative conceptions and was associated with activism, Thomas became associated with the dominant spheres: male, heterosexual, private, restrained, modest, etc.

Republican senators utilized aggressive lines of questioning that were laced with subtle and overt challenges to the validity of Hill's testimony. Ragan et al. found in an ethnomethodological analysis of the hearings that accusations and insults were incorporated into the Republican senator's statements during the hearings in order to achieve these goals (Ragan et al. 1996, 32). Another study on impression management presented in the book found that senators tried to repair Thomas' reputation by utilizing nonverbal communication. Emotions were intertwined in their statements in committee as 
opposed to a focus on rational and logical arguments to refute Hill's allegations. For example, the authors note that Senator Hatch used the raising of his voice at the end of lines of questioning to signal that he expected a "no" response to his inquiry (Ragan et al. 1996, 101-104).

There were also studies on verbal and non-verbal deception, as well as believability, and audience evaluations of selected portions of the hearings. These studies all are effective in raising a number of questions regarding the believability of Thomas, the fairness of the hearings to handle the allegations brought forward by Hill, and how issues of identity and power may have been more important and were otherwise overlooked by the public during the televised committee proceedings. The hearings showed that narratives were constructed for Judge Thomas by senators advocating on his behalf. This is in contrast to Hill, who forwarded her narrative by herself without an advocate on the Senate Judiciary Committee (Ragan 1996, 155-157).

Many of the senators that sat on the committee for the Hill-Thomas hearings remain in the Senate and were involved in the nominations of judges in the $110^{\text {th }}$ and $111^{\text {th }}$ Congresses. Senator Specter was involved in the Hill-Thomas hearings and is known for furthering the narrative that Anita Hill was a "scorned woman" and suggested in his questioning that she made up the sexual harassment story in order to seek revenge for Clarence Thomas refusing her romantic advances (Ragan et al. 1996, 153). While subsequent nominations, such as those of future justices Alito, Roberts, Sotomayor, and Kagan, did not involve allegations of sexual harassment, the presence of the same sitting senators gives cues as to where to expect language reinforcing heteronormative ideals. If 
Hatch was capable of using leading lines of questioning and raise his voice to get the responses he wanted, he could do it again during more recent nomination hearings. If Specter was able to formulate alternative motivations regarding individuals, he could do it again.

Although Ragan et al. (1996) indicate a bias towards believing the testimony of Anita Hill, the study raises significant points about how power dynamics came into play in the hearings. A panel of all male, white senators served as political jurists in a debate where the interplay between sex, gender, race, and status all intersected. Despite illuminating the existence of power dynamics in the committee setting, the case study is limited due to the fact that is has been two decades since the events transpired. Discourse analysis

Although modern research is predisposed to accepting the dominance of the white, male, middle class perspective, approaches dealing with power, language, and gender have an overlap with social constructionism: according to Alvesson and Sköldberg, they “avoid objectivistic assumptions and claims.” By utilizing discourse analysis, language can be examined to determine how reality is constructed and uncover the underlying assumptions at the core of society and social institutions. Reality is reproduced through the maintenance of norms within institutions. These norms are reinforced through the use of language. It enables the status quo and order to be maintained, and power is expressed through this construction (Alvesson and Sköldberg 2009, 228-229). 
Constructivist conceptions of discourse analysis attempt to understand how society perpetuates conceptions of power. A critical discursive analysis, applied in this study, seeks to understand the power dynamics that are perpetuated and their impact and consequences (Irving and English 2008, 108). There is not one distinct approach to discourse analysis, but several. There is no "right" answer in examining discourse, as there are multiple perspectives. However, the goal is to delve into the material in order to better understand the relational meaning that evolves throughout discourse (Gee 1999, 45). Language is not neutral, and investigation will reveal the presence of ideologies. While the subjectivity of such approaches may seem "unprincipled and inconsequential," the ability to understand more perspectives furthers debates (Widdowson 1998, 149). Uncovering power dynamics through discourse analysis means that, once seen, they cannot be unseen. And while Sedgwick argues that deconstructive analyses may not be enough to undo the constraints of binarisms, Burgess' argument that the practical effects lead to unworkable application of such theoretical constraints gives one hope (Sedgwick 1990, 10; Burgess 1999, 214).

Discrepancies based on gender perpetuate sexism. Dominance, perspectives, and attitudes typically associated with men are favored and reproduced, leaving the experiences of women to be disregarded. A critical feminist approach to nomination hearings will allow a critique of existing conceptions and structures in which discrimination based on gender, or "gender blindness," is exacerbated (Alvesson and Sköldberg 2009, 237). If societally established gender differences and constraints are based on discrimination inherent in the system, then they should be challenged and 
questioned in light of more diverse nominees to the Supreme Court. The system was established by wealthy, white, men and was crafted with language that did not grant equal status to a majority of its citizens. Although the Constitution has evolved over time, inherent bias based on the perspectives of those who crafted the system can still be perpetuated.

Discourse analysis follows post-structuralism, in that both approaches assume people to be inconsistent. There is a difference between language and external reality. The difference between the two is that discourse analysis is empirical and systematic as a research endeavor. All language is fair game: texts, speeches, documents, etc. It is also qualitative to solve the problem of emphasis on consistency and the occlusion of discrepancies. Qualitative research must avoid acknowledging multiple meanings and instead prefer a primary meaning. Alvesson and Sköldberg (2009) state that discourse analysis asks: "On what occasions are the different attitudes expressed? How are the utterances constructed? In what contexts are they included and what functions do they fulfill?” (Alvesson and Sköldberg 2009, 229-232).

The benefit of dealing with documents and texts, as opposed to interviews with subjects, is that there is no researcher influence upon that which is being studied. It is also useful because comparing the accounts given from the perspectives of different individuals allows the researcher to uncover the constructive meaning revealed by the conflicting views and statements (Potter and Wetherell 1987, 162). Reviewing a limited set of circumstances will help elaborate upon the experiences of individuals, such as women, which will limit over-generalizations (Alvesson and Sköldberg 2009, 240). As 
society changes over time, we should not expect previous women nominated to the court, such as O’Connor and Ginsburg, to have the same experience as Sotomayor and Kagan (Alvesson and Sköldberg 2009, 103). By reviewing the most recent Supreme Court nomination hearings before the Senate Judiciary Committee, the limits of confining debates of constitutional theory between categorizations between judicial restraint and judicial activism will hopefully be revealed in the face of more diverse nominees that do not fall within the construction of prevailing heterosexist norms.

Reviewing a forum as highly salient to the public as Supreme Court nomination hearings will allow for the revelation of inconsistencies in the treatment of different nominees. The rigidity of previously identified dichotomous pairings in the face of increasingly diverse nominees will, if Queer New Institutionalism is correct, lead to the failure of the confining categorizations to adequate explain the judicial philosophies of the individuals that appear before the committee.

As queer theory identifies the dichotomous relationships between heterosexual and homosexual spheres as well as others, such as white/black, male/female, Burgess focuses on what she calls the "central binarism of constitutional theory," the ongoing debate over judicial restraint and judicial activism (Burgess 1999, 204). Echoing the sentiments of Sager (2004), she challenges Americans to ask why constitutional interpretation is decided by unelected individuals far removed from the democratic process (Sager 2004, 3). Burgess goes one step further than Sager, and argues that judges interpret the Constitution without an objective standard. Lacking a consensus among the electorate in order to make rulings, she believes that it is not possible for judges to argue 
that they make decisions objectively and absent from political influences (Burgess 1999, 205-206).

Burgess calls for judges that make decisions utilizing common conceptions of gender, race, and class. Often absent from these interpretations are critical analyses of the biased system favoring patriarchal dominance and heterosexist understandings. By highlighting examples in which scholars argue for a restrained interpretation of the constitution fashioned from an objective and neutral position while simultaneously utilizing sexualized language, Burgess convinces the reader to consider the implications of unchallenged assumptions about heteropreference and engendered patriarchal dominance (Burgess 1999; 206-208).

The Senate Judiciary Committee holds hearings for judicial nominees selected by the president where debates regarding constitutional theory are ongoing. Nominees are questioned to identify their views and assess if they are within the mainstream of the American populace. The problem, as confirmed by authorities on either side of the debate, is that interpretations of the Constitution are constructed as being discrete and oppositional. Queer New Institutionalism calls attention to the effects of this construction: perpetuation of the status quo, in which heteronormative and sexist preferences that are built within our system of governance are reinforced and perpetuated.

Each section will focus on the individual nominees before the Senate Judiciary Committee. Chapter 2 focuses on the nominations of John Roberts and Samuel Alito during the $109^{\text {th }}$ Congress. Chapter 3 focuses on the nominations of Sonia Sotomayor and Elena Kagan during the $111^{\text {th }}$ Congress. The four hearings will be examined for the use 
of words spoken by senators and witnesses before the committee to reinforce heteronormative expectations and behavior. Then, metaphors will be identified as well, in search of support for the theory of Queer New Institutionalism. Finally, the important binary pairs emphasized during each nominee’s confirmation hearing will be examined. 
2. Methods and Judicial Nominations during the $109^{\text {th }}$ United States Congress

Following the theory of Queer New Institutionalism, there is no objective approach regarding how to interpret the United States Constitution. By highlighting dichotomous pairings, Burgess (1999) argues that sexualized language is used to reinforce institutionalized norms that perpetuate asymmetrical power structures. For example, majority spheres of influence are associated with that which is male, white, heterosexual, rational, and judicial restraint. But these dominant groups depend upon the existence of their counterparts, the Other, minority spheres comprised of female, black/non-white, homosexual, irrational/empathetic, and judicial activism (Burgess 1999, 204-205).

Again, this study will answer the following research questions:

What are the underlying sexual themes that permeate nomination hearings for judges and justices before the Senate Judiciary Committee?

How are the heterosexist norms that are present in discussions regarding constitutional theory reinforced through nomination hearings?

What is the effect of the persistence of institutionalized heterosexist norms?

Following a social constructivist approach that incorporates perspectives derived from feminist and queer theories, among others, a form of discourse analysis was employed to review how senators on the Senate Judiciary Committee engage and vet nominees to the United States Supreme Court. Transcripts provided by the Senate Judiciary Committee on its website were reviewed, along with pre-recorded webcasts of Supreme Court nomination hearings provided on the committee's and C-SPAN's websites, in order to 
identify the main issue areas highlighted by the senators as well as specific instances of metaphors and explicit language directed towards the nominees in order to reinforce institutionalized heterosexist norms.

The study relies on the assumptions already presented by the theory of Queer New Institutionalism: that unequal spheres of influence exist and that heterosexist norms have been institutionalized within power structures, namely the male, white, heterosexual, rational, and judicial restraint perspective dominates at the expense of subverting that which is associated with the female, black/non-white, homosexual, empathetic, and judicial activism. The dominant spheres therefore cause the perpetuation of similar perspectives and reproduce the existing power structures. Burgess identified instances of sexualized language used by legal scholars to reinforce these dichotomous pairings. Following a social constructivist perspective, it is assumed that language continues to reproduce the existence of these power structures in reality (Alvesson and Sköldberg 2009, 28).

With the theory of Queer New Institutionalism set as the basis for the study, individual cases can be examined in order to determine how they fit within the confines of the theory. Using this process of abduction, the theory can be further developed with the goal of being able to apply it to more cases than those previously identified. In contrast to induction and deduction, further testing of Queer New Institutionalism with empirical data will allow the theory to be modified and refined, thus expanding understanding (Alvesson and Sköldberg 2009, 4).

Setting 
The setting for the study is the Senate Judiciary Committee nomination hearings for the U.S. Supreme Court during the $109^{\text {th }}$ and $111^{\text {th }}$ Congresses, for the four most recently appointed Supreme Court justices. As a standing committee, it is charged with fulfilling the Senate's duty in approving judicial nominations by the president. These hearings take place before the committee in the Hart Senate Office Building. Tradition allows the nominee to come before the committee in order to give testimony and answer questions from the members (Senate Judiciary Committee website 2011). Sample and Participants

The Senate Judiciary Committee provides detailed records on its website for nominees to the courts. Available for the public to access are documents, written responses from nominees to questions from senators, background information, prior works provided by the nominees, as well as audio and visual records, including those of the nomination hearings themselves. Given the importance of Supreme Court nominations, the 18 Democrats and Republicans that comprise the committee are present to ask the potential justices questions. Only 17 Chief Justices and 112 associate justices have ever been selected to be on the Supreme Court (Senate Judiciary Committee website 2011).

The difference in the political arena during the two Congresses allows for a type of natural experiment to be conducted. The nominees selected during the $109^{\text {th }}$ Congress, John Roberts and Samuel Alito, were made by a Republican president, George W. Bush, and testified before the Senate while it was controlled by Republicans. During the $111^{\text {th }}$ Congress, nominees Sotomayor and Kagan, were selected by a Democratic president, 
Barack Obama, and testified before the Senate while controlled by Democrats. While there were changes in those that sat on the committee, many of the senators remain the same across all four nomination hearings. The primary difference is then that $109^{\text {th }}$ Congress was presented with nominees selected by a Republican, the $111^{\text {th }}$ by a Democrat. Also important, with the context of the theory of Queer New Institutionalism, is that the nominees made by President Bush, Roberts and Alito, were both white men, whereas those made by President Obama were female, Sotomayor, a Hispanic woman, and Kagan, a white woman (Senate Judiciary Committee website 2011).

\section{Measurements}

The framework outlined by Berger and Luckmann in The Social Construction of Reality (1966) serves as the basis for the deconstruction prescribed by Queer New Instititonalism. There is power in language, and words serve as basic units to be built into metaphors. These metaphors in turn are used to construct reality. Reality is then reproduced through generations in order to construct subsequent individuals (Berger and Luckmann 1966, 64-67; Alvesson and Sköldberg 2009, 28). Burgess’ argument for a Queer New Institutionalism relied on revealing the underlying heterosexist bias of the institutions in society. She was able to highlight these by looking for accepted ideas related to the law which utilized sexualized language. In her review of Wechsler's “Toward Neutral Principles of Constitutional Law,” she noted his use of the phrase “naked power organ” to describe the U.S. Supreme Court. Another example she mentions is the colloquialism "he got Borked," with its sexual connotation, established after the 
nomination of Robert Bork to the U.S. Supreme Court failed to pass a vote in the Senate (Burgess 1999, 207-209).

These examples fit within the framework initially noted by Berger and Luckmann (1966) and serve as the basis for Burgess’ research. They remain a starting point in attempting to deconstruct the assumptions accepted as default and natural when considering aspects of the law, such as nominations before the Senate Judiciary Committee examined in this study. Taking the asymmetrically dichotomous pairings illustrated by Burgess, such as male versus female, white versus black, heterosexual versus homosexual, reason versus desire, judicial restraint versus judicial activism, etc, words, metaphors, and issue areas were sought that would fit within the construction of these binarisms. In Burgess’ example of Weschler's text, the phrase “naked power organ” referencing the United States Supreme Court was effective in contrasting the majority spheres, the male, heterosexual, and reason, with the minority Others, such as female, homosexual, and desire. After this distinction is elucidated, Weschler then called for the application of "neutral principles” thereby “clothing” a Supreme Court which would otherwise be a “naked power organ.” By making this charge, Weschler completes the linkage ascribed by Queer New Institionalism: judicial restraint belongs in the majority spheres of the pairings. Judicial restraint represents the male, white, heterosexual, reasoned perspective. This relegates judicial activism to the female, black (or non-white), homosexual perspective, driven by desire (Burgess 1999, 208-210).

First, this study will attempt to identify the single words that serve to reinforce the dichotomous pairings previously outlined. Those that have sexual connotations or double 
entendres serve to contrast binarisms as discussed. Second, phrases and metaphors are also located to distinguish between the spheres presented. If Berger and Luckmann's (1966) theory regarding the legitimization of knowledge hold true, such instances function in constructing reality and subsequently reproducing it (Alvesson and Sköldberg 2009, 28).

The nominations during the $111^{\text {th }}$ Congress, the most recently completed Congress, saw the nomination and confirmation of two more women to the U.S. Supreme Court. Given the previously outlined dichotomous pairings, Sotomayor and Kagan display several characteristics that represent the Other and maintain minority positions that threaten the pre-established and accepted social and institutional order. Alito and Roberts, nominated during the $109^{\text {th }}$ Congress, were conservative, white men. They were both married, heterosexual (presumably), and had children. Both had served previously as federal judges (U.S. Senate 2005; U.S. Senate 2006). Sotomayor and Kagan, by comparison, were selected by a Democratic president and presumed to be liberal, both were single, career women without children. They mark the third and fourth women ever appointed to the Supreme Court. Sotomayor also had the distinction of being the first Hispanic nominee to the Court. Sotomayor had previously served as a federal judge. Kagan did not have experience as a judge, but served as dean of Harvard Law School and U.S. Solicitor General (U.S. Senate 2009; Marcus 2010).

Third, issue areas will be identified that reinforce the differences apparent in the nominees from what is required following the traditional and accepted majority: white, heterosexual males that adhere to judicial restraint in their approach to constitutional 
theory (Burgess 1999, 203-204). These issue areas represent the main topics that Senators reference in their lines of questioning. Many are repeated and utilized in order to damage or derail the nominee's credibility, reputation, and ability to interpret the law and Constitution within the mainstream of American public opinion (Gibson and Caldeira 2009, 140).

As working women, if Queer New Institutionalism is correct, nominees Sotomayor and Kagan represent a threat to the preconceived notions of what a justice to the Supreme Court should look like. These are two individuals who focused on their careers and succeeded. They are unmarried and have no children. Sotomayor is the first Hispanic woman to be nominated to the Supreme Court. By remaining unmarried, both women challenge the assumption that the heteropatriachal family is the basic unit required by society in order for success (Burgess 1999, 201). Therefore, we would expect that words and metaphors used during the hearings will emphasize the Otherness of these nominees and subsequently, the issue areas considered by the Senators that subscribe to these biases favoring traditional constructions of society and institutions will relate to them as well (Burgess 1999, 205).

Applying discourse analysis

Following discourse analysis as outlined by Potter and Wetherell (1987), ten steps are taken towards a better understanding of the conversations approached: identifying research questions, selecting a sample, collecting records and documents, interviews, transcription, coding, analysis, validation, reporting, and application (Potter and Wetherell 1987, 160-174). Although interviewing is a key part of the process for the 
authors, Gee (1999) states there is more than one way to approach discourse analysis, and the main task it to understand language in use (4-5). This allows for interviewers to be less rigid in conducting research with subjects. Instead of a formal survey which might rely significantly on yes/no or other structured responses, the authors argue that a less formal approach allows for responses which are more useful to the researcher in understanding the construction and function of discourse. What is important about this portion of their research design, as it is absent from a discourse analysis of Supreme Court nomination hearings, is that the researcher is forced to adapt due to the less rigid interaction. The researcher reacts and can respond to the interviewee's responses with new questions. Thus, the researcher's responses must be recorded and analyzed and not just the respondent’s. (Potter and Wetherell 1987 164-165).

In a study that does not have interviewers, but still approaches language and the construction and function it serves within discourse, the researcher must also not be excluded from the analysis. The use of abduction in research allows for a single case to be investigated while interpreting it using an overarching pattern previously established by theory, Queer New Instititoinalism in this instance, which then explains the case in question. Although it shares similarities with both induction and deduction, it is not the same or simply a mix of the two. It adds new features: the investigation from the perspective of the theory leads to new insights and then allow for adjustment and refinement of the overarching theory going forward. Also, it incorporates understanding, allowing for reflexive research that incorporates and acknowledges the researcher 
conducting the study and their relationship with the subjects engaged (Alvesson and Sköldberg 2009, 4).

Unlike content analysis, discourse analysis allows for deeper understanding in analyzing language. Instead of simply counting instances in which certain words or phrases arise during the conversation, discourse analysis seeks to categorize the content into relevant areas (Potter and Wetherell 1987, 167). From this point, the documents are read in order to establish patterns and thereby determine the function and consequences of the language (Potter and Wetherell 1987, 168).

The primary sources of data were transcripts and video from the proceedings. Pursuant to Burgess' theory, instances of sexualized and gendered language that revealed the reinforcement of binarisms were identified (Burgess 1999, 207, 213). Specifically, the nomination hearings of the four justices were reviewed for sexual language that does serve the purpose of reinforcing constraints and then it was searched to identify similar language across the nomination hearings. This allows for further identification of power imbalance, as certain gendered/sexualized language may be attributed to one type of nominee over others (for example, directed towards women and not men).

After identifying the presence of this language, it was examined within the context of the discourse to see how/if it reinforced common binarisms as identified by Burgess and Sedgwick (heterosexual/homosexual, male/female, white/black, reason/desire, judicial restraint/judicial activism, democratic authority/individual rights, etc. (Burgess 1999, 200, 217). Following Queer New Institutionalism, it is in these instances where incoherence of theoretical constraints based on dichotomous pairings 
will reveal themselves as they are applied practically (Burgess 1999, 214). And according to Sedgwick, after this occurs and the presence of a minoritized Other is absent, those that previously reinforced the binarisms will being to transit the boundaries between the pairs (Sedgwick 1990, 124-125).

The Nomination of John Roberts to the United States Supreme Court

In the summer of 2005, after the death of Chief Justice William Rehnquist, President Bush nominated John Roberts, a U.S. Appellate Court judge, to replace him. Originally nominated to replace retiring Justice Sandra Day O’Connor, the passing of the chief justice prompted the president to elevate Roberts to the head role on the Supreme Court. It was the first Supreme Court nomination hearing in 11 years and only the $17^{\text {th }}$ chief justice nomination in U.S. history (U.S. Senate 2005, 2, 4, 6, 7, 21).

Judge Roberts was nominated when the Senate, and thus the Judiciary Committee, was controlled by Republicans. The Senate Judiciary committee was comprised of Democratic members Patrick Leahy (who was later the chairman of the committee during the $111^{\text {th }}$ Congress), Edward Kennedy, Joe Biden, Herbert Kohl, Dianne Feinstein, Russ Feingold, Charles Schumer, and Dick Durbin. The Republican majority on the committee was comprised of members Orrin Hatch, Charles Grassley, Jon Kyl, Mike DeWine, Jeff Sessions, Lindsey Graham, John Cornyn, Sam Brownback, Tom Coburn, with Arlen Specter as the chair of the committee (he later switched parties and was a Democrat during the $111^{\text {th }}$ Congress) (U.S. Senate 2005, ii; U.S. Senate 2009, ii).

The nomination hearings before the committee took place on Capitol Hill on September 12th through the $15^{\text {th }}, 2005$ (Roberts 2005, iii). The setting for the nomination 
hearings was during the aftermath of Hurricane Katrina, which devastated New Orleans. Being the first nomination hearing in over a decade, a significant portion of time was spent by the senators probing Judge Roberts on the bounds of what he was willing to answer in his testimony. Reference was made at several points during the proceedings to the "Ginsburg Precedent," her view that a nominee should give "no hints, no forecasts, no previews” during the committee hearings as to how they would rule on a case before the Court (Roberts 2005, 377). Although Roberts followed this rule, he was chastised by senators for not being more revealing. This was especially true for Senator Schumer, who charged that Roberts would “cite it when you don't want to answer something” (Roberts 2005, 260). This reveals the committees, as well as the nominee's, challenge: to use the hearings to uncover as much as possible, but not so much that the future justice has prejudged all the cases that are to come before the Court or passed a litmus test.

At the beginning of the hearings, several Republican senators made reference to the Supreme Court being a "super-legislature" and justices acting as "super legislator[s]" citing the prevalence of 5-4 decisions from the Court as evidence that the body had become politicized. Chairman Specter told the committee that appointing a new Chief Justice would provide opportunity to "rebuild the image of the Court." The repeated use of the same term, super-legislature, signifies a coordinated partisan effort in approaching the committee hearings, at least at the outset. Senators Specter, Grassley, Brownback, and Cornyn used their opening statements to frame the debate within the confines of the established binarisms of judicial restraint and activism: the Court has become politicized and was thus controlled by activists. It should not be a "super-legislature" and instead 
must be returned to the status of a neutral arbiter, and by acting in concert, Judge Roberts’ supporters can make it their duty to do so (Roberts 2005, 2, 13, 41, 46). Specter also made use of the terms "super-stare decisis" and "super precedents" to reinforce an ideological position he holds: that Roe $v$. Wade and a woman's right to choose had been reinforced by the Court so many times, that it cannot and should not be overturned. After 38 cases which solidified the holding of Roe v. Wade, he wanted Justice Roberts to assure him that he would not be a vote against abortion rights (Roberts 2005, 144-147). This is an example of language used to reinforce an ideological position which did not fall along party lines. Democrats questioned Roberts about abortion rights as well, but did not use the same terms as Specter. Republican Senator Hatch said "I am not sure a super-duper precedent exists” (Roberts 2005, 159). And Senator Brownback cites Plessy v. Ferguson as proof that super-stare decisis does not exist. Despite the Court reaffirming “separate but equal” in numerous cases, it was overturned (Roberts 2005, 289). This discussion among the Republican senators shows that some issues cross partisan lines, and while they might debate each other cordially, there is significant disagreement over the role of a justice in deciding on such matters.

\section{Questioning identity}

Like the Supreme Court nominations during the $111^{\text {th }}$ Congress, those during the $109^{\text {th }}$ Congress did not occur in a vacuum. The media reported on the President's selection of Judge Roberts to be the new Chief Justice prior to the nomination hearings. And, like Kagan, questions arose regarding Robert's sexuality. On August21, 2005, the New York Times published an article comparing Robert's association with a nascent 
conservative movement on campus at Harvard with the marginalized status of homosexuals. It ran with a picture of Roberts and two male friends (Scott 2005).

The article reinforced the point made by Sedgwick (1990), that homosexuality ceases to be merely a description of a sexual act between two persons of the same gender, and instead comes to refer to an identity, where the association of two persons based on factors other than sexual acts is come to be known as homosexual (45-47). It is implied by the article, possibly meant to fuel speculation in much the same way as the Wall Street Journal did by publishing the picture of Kagan playing softball, that Roberts is a homosexual, and a closeted one at that. As if three men pictured with a pie they made in the 80s and a quote comparing conservatives with queers has the ability to rewrite history in order to label some homosexual (Appendix A). Unlike the photo of Kagan, it did not appear to gain traction because Roberts eventually confirmed to heteropreferential norms: he is married man and has children. Questions of sexuality were central during Kagan's nomination hearing, with repeated references to controversy surrounding Don't Ask Don’t Tell and the Solomon Amendment. While questions regarding same-sex marriage arose during Roberts' nomination hearing, they were not central (U.S. Senate 2005, 148149).

Using words to reinforce binarisms

In a particularly telling exchange between Senator Cornyn and Roberts, the Senator describes the United States under the Articles of Confederation. He says that the federal government was "impotent" under such a document, and it led to the drafting of the current Constitution at convention. This was immediately after a discussion between 
the two over neutral principles and the need to follow stare decisis (U.S. Senate 2005, 270-271).

Cornyn uses sexualized language to frame the debate, defining the U.S. Constitution in a mutually dependent relationship with the Articles of Confederation. The binarism therefore invokes a reference to the penis: the federal government was incapable and ineffective under the "impotent" authority of the Articles of Confederation (U.S. Senate 2005, 271). The Articles had no enforcement power over the states, and by utilizing a sexualized term, Cornyn is able to associate the Articles with the feminine, homosexual, and non-white while reserving the Constitution with the masculine, heterosexual, and white. The federal government desired control over the states, but was emasculated and impotent under the Articles, unable to be effective and enforce power. The U.S. Constitution, replacing the articles, is strong and is master over the states. Having stamina and endurance, it has endured through time. And it is potent, adjudicating over effective, productive government (Burgess 1999, 204).

However, once again the inconsistency of the dichotomous pairing emphasized by the sexualized language is revealed when applied in practice. The Articles of Confederation were impotent, but to replace them a constitutional convention was held. It was an instance of activism: the drafting of a new governing document to replace the Articles. It was not through the reason afforded by the Articles that a more virile governing document evolved. It was through the desire to subject the states to the dominance of a stronger federal government and working outside the bounds of selfimposed constraint that allowed for their replacement. Ironically, praise is given for the 
endurance of the U.S. Constitution, but it was forged through a process which is abhorred by the most ardent of its supporters on the committee, such as Cornyn. By labeling the Articles of Confederation as impotent, he outs his desire for the Constitution, and his association with the homosexual by focusing on phallic terminology.

\section{Judicial restraint/judicial activism}

The Republican committee members repeatedly and emphatically state that the Court should be an objective body, free from politicization. Multiple senators reinforce the dominant sphere of the judicial restraint/judicial activism binarism. Specter wants a Court of “consensus” (Roberts 2005, 2). Grassley praises Roberts as a replacement for Rehnquist, who exercised “judicial restraint” (Roberts 2005, 13). Kyl says that the Supreme Court is not a "political office," thereby reinforcing the idea that the Supreme Court should follow neutral principles (Roberts 2005, 19). Sessions warns that activism is a judge ruling based on the desired outcome, to see policy preferences enacted (Roberts 2005, 30). Brownback tells Roberts that the Founding Fathers wrote about restraint, and uses a baseball metaphor to reinforce his position: a judge is like an umpire and therefore cannot play on the field; a judge cannot rule in favor of their policy preferences. To do so, would further tear our country apart. He gets emotional as he notes the political division that plagues American society (Roberts 2005, 46-47). Over and over, at different times and citing different examples, the Republican committee members appealed for a justice who will adhere to the confines of judicial restraint.

Returning to the idea of super-precedence, Brownback attacked the idea of repeated reinforcements of the holdings of a case as being irreversible. Roe $v$. Wade may 
have been reinforced in 38 subsequent cases, but that does not necessarily make it the correct decision. Brownback cites the landmark Brown v. Board of Education case, which overturned Plessy v. Ferguson and found separate but equal to be unconstitutional as a seminal event in which the Court overturned existing precedent. He goes on to note "the Supreme Court has overruled itself in 174 cases” involving constitutional issues (Roberts 2005, 47).

After characterizing Roberts as a justice who will adhere to judicial restraint, and after Republican senators repeatedly and thoroughly praised and called for a replacement justice that would adhere to neutral principles, be an objective arbiter, and exercise restraint, Brownback in the absence of an Other representing judicial activism skirts the line between the dichotomous pairings of judicial restraint/activism (Sedgwick 1990, 124-125). He then outs himself by appealing for the need of a justice to overturn Roe $v$. Wade for the benefit of the country. The constraints of the dichotomous pairings prove to be unworkable when applied to the practical issue of abortion. After subscribing to calls for restraint, objective application of the law, and judging based on neutral principles as his Republican peers do, the Senator allows himself to cross the line drawn between mutual dependent asymmetrical pairings: suddenly he favors desire instead of reason, activism instead of restraint. Of course, it is not that Senator Brownback suddenly changed his mind; it is just that the illogical incoherence of the binarisms were unable to be maintained when moved from the theoretical and applied to the practical (Burgess 1999, 212-214). 
Brownback’s statements allow the underlying and transitive sexuality that links the binarisms outlined by Queer New Institutionalism. The dominant spheres are male, white, heterosexual, utilize reason, exhibit judicial restraint, and apply neutral principles. But in stating his preferred policy preference to outlaw abortion, Brownback reveals his desire and appeals to emotions, decrying the exercise of "raw political power" that the Supreme Court exhibited in deciding Roe v. Wade. But by following the "neutral principle” of privacy as afforded by the Constitution, the result is that a woman's right to choose was found to exist within the document and the result is that " 40 million children have been aborted” and Brownback describes them as "innocent faces that bless our existence” (Roberts 2005, 47).

He therefore rejects reason and the judicial restraint called for previously, and instead appeals to the minority spheres of the dichotomous pairings: judicial activism and a Supreme Court that is a naked power organ to act in overturning Roe v. Wade. He is then associated with those minorities, such as women, non-whites, homosexuals, which are oppressed, repressed, discriminated against, and ignored, in allowing his desire for a policy preference be exhibited. His testimony before the committee thus reveals the incoherence of the binarisms he and his fellow senators previously reinforced. The inherent contradiction thus revealed, the Supreme Court is labeled activist for ruling for privacy in Roe v. Wade, but this also necessitates an activist decision from the body to overturn such precedent. The closet door was opened during the Roberts confirmation hearing and the logical inconsistency of neutral principles/naked power organs, judicial restraint/judicial activism, reason/desire, etc revealed. 
The Nomination of Samuel Alito to the United States Supreme Court

In 2005, Judge Samuel Alito was nominated by President Bush to the Supreme Court to replace retiring Justice Sandra Day O’Connor (Gibson and Caldeira 2009, 139). Alito's confirmation hearing took place a few months after Chief Justice Robert's, on January 9th through the $11^{\text {th }}$, 2006 (U.S. Senate 2006, iii).

Although Alito was generally praised for his candor in answering questions, there were also several issues raised repeatedly in attempts to challenge his nomination (U.S Senate 2006, 516, 559, 574). One such issue was Alito’s failure to recuse himself from the Vanguard case in 2002, where he decided in a case for a company with which he held a mutual fund (U.S. Senate 2006, 32, 388). Another was Doe v. Groody, a case where Alito ruled in favor of police who stripped searched a 10 year old girl after executing a warrant against a suspected drug dealer (U.S. Senate 2006, 331). These issues were used to paint Alito as being of questionable ethics by failing to recuse himself as well as predisposed to ruling in favor of the government.

Using words to reinforce binarisms

Reinforcing binarisms could not have been done more succinctly than when Senator Specter used the term "flaming liberal” in contrast to an "arch-conservative" during Alito's nomination hearing. He stated that, by examining the right set of cases, Judge Alito could be described as either. By contrasting the pairings and noting that Alito could be construed within in the confines of either, he is simultaneously identifying and outlining binarisms, while rejecting their flaws (Alito 2006, 3). 
Flaming liberal thus encapsulates several minority spheres in one term. The word flaming is normally associated with a homosexual, typically an effete one that is unable to conceal his sexual orientation, and in this instance is used to describe a liberal. By pairing the two words, it denotes judicial activism as well as desire, by characterizing someone as desiring certain progressive policy outcomes. The combination of these minoritized terms, female, homosexual, desire, and judicial activism, therefore signals a threat to their valorized counterparts: male, heterosexual, reason, and judicial restraint. By connecting these minoritized Others, the flaming liberal is elevated to a significant threat over the arch conservative. By defying predetermined heteropreferential norms, it is a challenge to their political values as well as their sexuality (Valenti 2008, 94-96; Burgess 1999, 204).

However, Specter quickly dismantles this dichotomous pairing by noting the ease in their construction. By selectively assembling cases from Alito’s history as a judge, a narrative can be crafted to make either association. So while he appeals to stereotypical conceptions of identity in his willingness to use the terms, Specter also breaks them apart by showing the futility in applying them to Judge Alito.

\section{Judicial restraint/judicial activism}

Similar to what occurred during Robert's confirmation hearing, senators on the committee spent a significant amount of time reinforcing the judicial restraint/judicial activism binarism. Perhaps this is to be expected, given the proximity in time between Alito and Roberts' nomination hearings. The binarisms built up over time were again 
proven unworkable by Senator Brownback’s emotional appeal to overturn precedent, and then joined by Senator DeWine (U.S. Senate 2006, 46-47, 390-391).

\section{White/black}

In several instances during Alito’s nomination hearing, a debate arose over the significance of race. Senator Durbin raises the question of race in reference to the Riley $v$. Taylor case, in which the need for removing African Americans on the jury was discussed. Durbin noted that Alito compared the significance of an all-white jury "as relevant as the fact that five of the past six Presidents of the United States have been lefthanded” (U.S. Senate 2006, 457). While Durbin is asking Alito to acknowledge the disparity and power asymmetry associated with white and non-white identities, Alito’s comments appear to indicate a disregard for race.

By appealing to the power imbalance between racial identification, Durbin wants Alito to acknowledge the possibility of discrimination based on race. While Durbin does not invoke sexualized language during this discussion to emphasize his point, it is a discussion of the white/black binarism and shows Alito operating within it based on prior comments. The dominant position of whites in society affords them the ability to look at the world without consideration for race. Although being white is being a part of a race, that dominant position allows members of the dominant group to assume their position as being natural (Wing 1997, 45).

Durbin's emphasis on Alito commenting about the insignificance of all-white juries in deciding a case against a non-white person is his appeal for Alito to reject binarisms of white/black. He wants the judge to view the world from the perspective of a 
person who does take race into account. This is because the non-white individual knows that others are able to perceive his race in association with others of the minority sphere.

Senator Kyl again invokes the image of lady justice, describing her as blind with the scales of justice. He uses her to illustrate how we place trust in our system.

Individuals put their freedom and fate into the hands of judges (U.S. Senate 2006, 515). But while judges do not want to cast decisions based on a person’s identity, Durbin’s question illustrates the point, without evoking imagery, about the problems that could arise when judges fail to acknowledge discrimination on the part of other members of society.

Democratic authority/individual rights

Another persistent theme during Alito’s nomination hearing was the claim from his opponents that he would be a consistent vote on the Court in favor of the government and against individual rights. The judge's ruling in Doe v. Groody illustrates this threat and was mentioned repeatedly by senators and witnesses before the committee. In that case, police were issued a warrant to search a man for drugs. It was believed that he hid drugs on other people within the same premises, so a 10 year old girl was stripped search and Alito ruled that that was permissible (U.S. Senate 2006, 635). Opponents used this case to assert that Alito continually gives undue deference to law enforcement and government authorities.

Senators were concerned with this given the context of the hearings, in which the President was pushing to extend the limits of executive power in the War on Terrorism. Alito’s belief in the Unitary Executive Theory was cited by Senator Schumer, one of his 
most vocal opponents on the committee, as reason for concern. Schumer said that Alito's "deferential and absolutist" view of the separation of powers between the three branches of government were concerning, citing his willingness to allow the president to execute warrantless wiretaps and expand his authority under inherent powers of the Constitution (U.S. Senate 2006, 37-38).

Witnesses before the committee warned that Alito would pose a threat to individual rights as well. Predictably, witnesses in favor of civil rights and a woman's right to choose were opposed to Alito as a conservative jurist. Fred Gray, a civil rights attorney, and Kate Michelman, the former president of NARAL Pro-Choice, argue against his nomination for those reasons (U.S. Senate 2006, 728-733). Berkeley law professor Goodwin Liu, also argued against Alito's nomination, arguing that although he is not an ideologue, his opinions consistently favor the government and impinge on individual liberties (U.S. Senate 2006, 690-692).

This attempt to place Alito within the confines of the democratic authority/individual rights binarism, as if there has to be a choice between one or the other, also results in him being removed or in conflict with the pairing of judicial restraint/judicial activism. If Alito would give deference to and respect the inherent powers of the president under the Constitution should be approved for the Supreme Court, he cannot be coherently argued to be a strict constructionist and a loyal adherent to judicial restraint. An interpretation of the Constitution that seeks to expand the powers of the presidency absent an amendment to the document is squarely within the judicial activist sphere as opposed to the dominant sphere of judicial restraint. Ronald Sullivan, a 
Yale law professor, argues this point, saying that Alito is not always a strict constructionist and "shifts his interpretive style when necessary to rule in accord with the government's interests” (U.S. Senate 2006, 635).

An analysis of the discourse during the nomination hearings of Roberts and Alito during the $109^{\text {th }}$ Congress might be expected to reveal little sexualized language and few binary constraints. However, this was shown not to be the case. Judge Roberts and his supporters in the Senate actively cast him as adhering to judicial restraint by using “neutral principles” (U.S. Senate 2005, 269-270, 411) and being a “neutral arbiter” (U.S. Senate 2005, 544). The media, if only briefly, attempted to incite suspicion that Judge Roberts might be a homosexual, or at least attempted to link him to that suspicion by characterizing conservatives at Harvard as being a minoritized Other (Scott 2005). Sexualized language was used during Roberts’ nomination hearing, with Cornyn describing the federal government under the Articles of Confederation as being “impotent” and thereby elevating the power of the Constitution within the confines of a binarism of his own creation (U.S. Senate 2005, 271).

During the Alito nomination hearing, opponents to the president's selection to replace retiring Justice Sandra Day O’Connor attempted to depict him as being out of the mainstream and too conservative to replace her on the Court. To illustrate the point, senators and witnesses alike tried to define Alito within the confines of a democratic authority/individual rights, saying that he shows deference and inherent belief in a powerful executive and therefore would upset the separation of powers and checks and balances between the branches of government. There was also instance of sexualized 
language as Senator Specter used it in drawing attention to the contrasting pairs of a flaming liberal/arch conservative. However, this was done to refute a binarism in attempting to define Alito within a construct that lacked nuance and was incoherent (U.S. Senate 2005, 3). 
3. Supreme Court Nominations during the $111^{\text {th }}$ United States Congress

Democrats, now controlling the Senate, also controlled the Judiciary Committee. Senator Leahy, formerly ranking member during the 109th Congress, became the Chair. Former Chairman Specter switched parties and relinquished control of the committee, but remained on it as a Democrat. During the 109th Congress, there were 10 Republicans and 8 Democrats; for the 111th there were 12 Democrats and 7 Republicans. This included the addition of Democratic Senators Cardin, Whitehouse, Kaufman, and Franken, as well as a second woman, Klobuchar. Senator Biden had become Vice President, and Senator Kennedy had passed away. Republican Senators Sessions, Hatch, Grassley, Kyl, Graham, Cornyn, and Coburn remained on the committee for the 111th Congress, while Dewine and Brownback did not. The Supreme Court nominees to be presented before the committee during the $111^{\text {th }}$ Congress include Judge Sonia Sotomayor and Solicitor General Elena Kagan (U.S. Senate 2009, 1).

The Nomination of Sonia Sotomayor to the United States Supreme Court

Judge Sonia Sotomayor was nominated to be an associate justice to the Supreme Court by President Barack Obama in 2009 to replace retiring Justice Souter. She came to the committee with 17 years of prior judicial experience. She was also the first Hispanic nominated to the Supreme Court. Her nomination hearing took place during the summer of 2009 before the 19 members of the Senate Judiciary Committee in the Hart Senate Office Building. The nominations proceeded with members asking questions and discussing her background and qualifications in order of rank for several rounds (U.S. Senate 2009, 1, 3, 5, 21). 
Many issues were covered during the week of hearings. The nominee was shown deference afforded her position as an experienced judge, with senators, Democrats and Republicans alike, referring to her as “Judge Sotomayor” or simply “Judge.” Topics typical of Supreme Court nomination hearings included discussions surround the Second Amendment and abortion (U.S. Senate 2009, 20), to less controversial issues such as allowing TV cameras to record Supreme Court proceedings (U.S. Senate 2009, 51).

Specific to the nominee were several discussions regarding Ricci v. DeStefano, a case in which she ruled as a federal judge, a dispute involving firefighters in New Haven, Connecticut and a test used for determining promotions and the use of race. As argued by Chairman Leahy, Sotomayor followed precedent and ruled unanimously as part of a three judge panel to defer to the lower District court's decision. By doing so, Sotomayor allowed for critics to charge that she was an "activist," "racist," and "biased," even though Leahy used his time during the nomination hearings to argue the contrary, that she was following established precedent in deciding the case, which was ultimately overturned by the Supreme Court (U.S. Senate 2009, 64-65).

\section{Using words to reinforce binarisms}

Also specific to the nomination of Sotomayor is criticism from the senators over remarks she gave during a speech, stating that a "wise Latina” would come to a better decision than others (U.S. Senate 2009, 7). Republican senators pounced on these comments, which were also highlighted in major U.S. newspapers (Markon 2009; Nixon 2009; Savage 2009). They use this to further charges that Sotomayor would use gender or ethnicity in coming to judicial decisions (U.S. Senate 2009, 18, 22-23, 26-27). 
Americans paying attention to the nomination hearings might be confused by senators highlighting the importance and historic nature of the first Hispanic woman nominated to the Supreme Court. The praise was accompanied by comments refuting the importance of identity and background used to influence a judge's consideration of a case and approach to the law. There is simultaneous support for the nomination of a diverse nominee along with criticism of Sotomayor's acknowledgement of the influence of her ethnicity and gender. This reflects a shallow reading of the impact and significance such characteristics play in the lives of Americans that comprise minority groups.

Such perspectives seek to simultaneously acknowledge and dismiss the importance of identity and reinforce the existing and enduring asymmetrical power inequalities of America's social institutions. This is a heterosexist perspective that continues to place importance on the views of those that constructed our system of governance: rich, white, males who enshrined discrimination into the Constitution. The tradition of considering racially inferior African Americans as well as depriving women of political and individual rights is a perspective that can easily order others to disregard considerations of race or gender in decision-making.

Analogies are often invoked in order to place people in the situation of others. It is an attempt to see the world from the perspective of someone unlike oneself. However, such exercises are limited because individuals are unable to remove the lense through which they view the world to completely experience what it is like to look through the lense of someone else. One who identifies with a particular group cannot escape looking at the world from behind that identity (Wing 1997, 44-45). For example, white people 
look at the world through the context of being white and even though it is a race, they do not see the world through a racial lense because of the dominant position of whites in society (Wing 1997, 45). Therefore, a system constructed from the dominant position is unable to allow for those belonging to the dominant group to completely understand how being subjugated, in practice and through tradition, perpetuates through the use of language or continued actions and behaviors that seek to require minorities to ignore the significance of their status within those groups.

Adding to discussions of groups in America, minorities and women are placed in dichotomous pairings that ignore other subsets. Therefore individuals who belong within multiple minority groups, such as black women or Hispanic women, are further isolated (Wing 1997, 306; Crewnshaw 2000, 210-214). Justice Sotomayor, as a Hispanic woman, belongs to two outgroups. This could allow her a perspective critical of the prevailing heterosexist conceptions of society where a "neutral" position is synonymous with the white, male perspective.

In discussing these Wise Latina remarks made by Judge Sotomayor, Republican Senator Graham indicates his concerns with the comments. He notes that, "If I had said anything remotely like that, my career would have been over” (U.S. Senate 2009, 27). This once again appeals to the heteronormative standard of ignoring race, gender, and the traditional and persistently dominant role white men have played in the construction and maintenance of our social institutions. For a white male to ask an individual who is of multiple outgroups, in this case Hispanic women, to be blind to identity is to accept de 
facto legitimacy of the prevailing view maintained by the dominant ingroup, white men (Burgess 1999, 202-203).

Therefore, ignoring identity is not necessarily synonymous with equality and acceptance of all individuals regardless of their demographics. It is instead an appeal to the status quo by an appeal for "gender blindness," where in this case ignoring gender delivers default legitimacy to the patriarchal conceptions of society (Alvesson and Sköldberg 2009, 237). By calling for judges that ignore race and gender, Graham is appealing to "universal rationality" that does not discriminate, but while ignoring identity, reinforces already institutionalized versions of discrimination where gender restraints are already functioning (Butler 1990, 12).

Graham proceeds to muse about his responsibility as a member of the committee: "If I give you this robe to put you on the Supreme Court...” He embarks upon the same line of thinking as Weschler as identified by Burgess. In speaking in terms of clothed/unclothed, he couples restraint with reason, and being unclothed/naked with activism and desire (Burgess 1999, 208,213). He states that Sotomayor's comments, including the Wise Latina speech, allow him a view of how she behaves "outside the courtroom without the robe” (U.S. Senate 2009, 27-28). In other words, outside of the courtroom, Sotomayor is free to act in ways that might not be acceptable for a Supreme Court justice. This is similar to the view expressed by Wechsler as deconstructed by Burgess. While more explicit and utilizing a more abstract metaphor, Wechsler described the Supreme Court clothed in "neutrality" as in opposition to one that operates as a “naked power organ” (Wechsler 1959, 12, 19). Burgess describes his article, which 
utilizes sexualized language, to embrace the binarism that underlies his argument, that the debate is a choice between judicial restraint and judicial activism or reason and desire. A Supreme Court that is clothed in neutrality is therefore seen as legitimate within this construction, by making use of logic and restraint, as opposed to the perverse nature of an unchanged and impassioned judiciary, one which is activist and driven by desire to reach decisions (Burgess 1999, 208).

This is similar to the imagery invoked by Graham. Sotomayor, without the restraint of her "robe" is free to reveal her true self when she makes appearances in public. Sotomayor, in delivering her Wise Latina speech, effectively "takes the robe off and says that their experience makes them better than someone else,” according to Graham (U.S. Senate 2009, 27). He discloses that he must decide whether or not to allow her access to the robe of a Supreme Court justice. He happens to have power as a senator (and a man) to decide if she (a woman) will be appointed to the Supreme Court (to a position that has been traditionally closed off to women). If he deems that she conforms to his expectations, he will give her the robe. He must decide if he can "clothe” her perceived judicial activism. By appointing her to the highest court in the land, Graham uses the robe figuratively to express his desire for her to be judicially restrained, but fears openly that she will continue to act nakedly, pursuing her passions and desires as an activist without restraint. Ironically, he must eschew her legal record in order to express his desire, for her to conform to his preferences and not act on hers.

Sotomayor's "fidelity" to the law is challenged throughout the hearings. This is despite her firm commitment and explicit comments to the contrary, 
"In the past month, many Senators have asked me about my judicial philosophy. Simple: fidelity to the law. The task of a judge is not to make law, it is to apply the law" (U.S. Senate 2009, 59).

Despite this assurance, backed up by her record as a judge, Sotomayor is challenged by Republican senators who believe that her previous comments in speeches that recognize identity are a threat to a restrained interpretation of the Constitution. Senator Cornyn, a Republican from Texas, describes his difficulty in reconciling her fidelity to the law as well as her past statements which recognize identity,

"I am struggling a little bit to understand how your statement about physiological differences could affect the outcome or affect judging and your stated commitment to fidelity to the law as being your sole standard and how any litigant can know where that will end" (U.S. Senate 2009, 330).

The repeated use of the word “fidelity” in Sotomayor's confirmation hearing should initiate debate on how it perpetuates heterosexist constructions within government, instead of just its use to indicate oppositional choice between the U.S. Constitution and the recognition of identity. First, it invokes a continued heterosexist conception of the Constitution and U.S. law because it appeals to already established patriarchal and heterosexual norms: that a woman should be married to a man, who is the head of a family unit (Burgess 1999, 203-204).

Within this conception, the U.S. Constitution is the authority to which one is to submit, much like the man is for the family, as husband and father he is the leader of the household and the authority to which members obey. The expectation is that a good wife will submit to her husband and remain loyal to him, and that this fidelity to him is to be rewarded, whereas disloyalty -cheating on her husband and infidelity - is to be shunned 
by society and threatens the family. In the same way, Sotomayor, as a woman, must submit to the Constitution and remain loyal to it, rejecting anything that strays from its authority which would also threaten pre-established heterosexual, patriarchal norms.

Feminists also critique the idea that men should demand that women claim fidelity to the U.S. Constitution. Catherine MacKinnon (2005) addresses this directly. She argues that it is a document which was crafted without her consent or the consent of women. She believes a moralizing view of the Constitution is one that sees it from the top-down in deciding what is good and bad, but that instead it should be crafted from the bottom-up, from the practical to the theoretical. In so doing it would reconcile how the Constitution permits the perpetuation of inequality, regardless of some principled approach to calling certain practices good or bad.

MacKinnon believes that fidelity works both ways, and that in order for her to be loyal to it, it must also be loyal to women. For example, she notes that the Constitution would be made more legitimate in the eyes of women were it to include an Equal Rights Amendment, so that when it did, women would see it as being more legitimate than compared with how it is now (MacKinnon 2005, 66-67, 70). The feminist perspective allows for a critique of the demands for "fidelity” to the Constitution, which suggests acquiescence to the heteronormative ideal. It demands that women, even as justices, act according to established cultural norms which serve as the basis for institutions like the Supreme Court. Simultaneously, putting nominees on the spot and refuting them en masse, as Republicans criticize Sotomayor for her Wise Latina remarks, ensures that 
alternative interpretations are downplayed or refuted before justices make it onto the bench.

The nomination of Sotomayor to the Supreme Court followed the prediction of Gibson and Caldeira (2009), where those that support a nominee attempt to emphasize their "judiciousness" and the opponents to the nominee stress that they are biased or out of the ideological mainstream compared to the rest of Americans (Gibson and Caldeira 2009, 140). In this case, Democratic senators such as Schumer, Leahy, and Klobuchar served as advocates for Sotomayor, emphasizing her legal record and judiciousness (U.S. Senate 2009, 24, 128-132, 360, 420). Conversely, Republican senators such as Sessions, Kyl, and Grassley use their time to demonstrate that she is biased or could be prejudiced in her rulings if confirmed (U.S. Senate 2009, 6-7, 16-17, 21-23).

Judicial nominations do not operate in a vacuum. The public is made aware of the nominee after the president makes his selection months before the confirmation hearing. Americans get their information regarding candidates through elites, such as the media and interest groups. Opponents to the nominee will attempt to frame the debate to emphasize political controversies in order to derail the confirmation (Gibson and Caldeira 2009, 142). This appears to have worked in the case of Sotomayor. Senator Klobuchar relays a story in which she was in the airport prior to the nomination hearings, when an airport worker and constituent from her home state asked "are you going to vote for that woman?” The worker explained to the senator their concern that Sotomayor would let her “emotions get in front of the law" (U.S. Senate 2009, 36). 
This exchange captures the debate of Sotomayor's concern for empathy in deciding cases. Through the nomination hearings, senators raised objections to the judge due to the fact that she might allow her feelings and emotions color her judgment in deciding cases. This plays within the reason versus desire binarism (Burgess 1999, 208) and in this instance links directly to the binarism of judicial restraint versus activism. The discussion illuminates the asymmetrical power relationship between the dichotomous pairings. Judicial restraint and reason are seen as the preferred approaches to the law, and the focus on Sotomayor's empathy allows for skepticism in her capabilities as a judge: she might use activism and her desire to further her preferences in regards to the law.

The fact that a constituent asked a senator if she would vote for "that woman" demonstrates the effectiveness elites had in framing the debate regarding Sotomayor's nomination prior to the hearings before the Senate Judiciary Committee. Newspapers reported on what were argued to be controversial aspects of Sotomayor's past (Markon 2009). This allowed for senators to capitalize on questions of her judicial temperament and capacity for allowing emotions into consideration in her rulings. President Obama, when nominating Sotomayor, said "depth and breadth of one's empathy" and "their broader vision of what America should be” was critical for judges (U.S. Senate 2009, 6). Senator Sessions, during the hearings, said “call it empathy, call it prejudice, or call it sympathy, but whatever it is, it is not law” (U.S. Senate 2009, 7).

These words were all spoken by persons other than Sotomayor. Again, despite her lengthy resume and years of service as a judge, those that were opposed to her were able to frame the debate by raising questions and drawing suspicion of her record. The word 
“empathy” served as a trigger, evoking disdain for anyone who would refute reason in favor of desire. In this framework, the two are diametrically opposed. The question of her ability to rule fairly as a judge was so suspect that it gave rise to the term "empathy standard” in regards to the possibility that she would consider emotions (U.S. Senate 209, $6,40)$.

By making the word empathy something worthy of derision and suspicion, Sotomayor's opponents were able to couple it with doubts over her ability to rule with restraint. If she is willing to consider identity and heritage, as her Wise Latina comments show, if she is willing to give consideration to the positions of others and has empathy for those that come before her, then she will be willing to go beyond what is demanded by the law and the Constitution and rule in favor of her unreasoned preferences. She will be an activist, giving consideration to standards outside of the heteropatriarchal norms.

The effectiveness of framing the nomination within these binarisms, restraint versus activism and reason versus desire, put Sotomayor and her supporters on the defensive. Sotomayor herself spent time, when talking about rulings she delivered in prior cases, to note that despite where her sympathies lied, she followed what was demanded by the law in delivering her rulings (U.S. Senate 2009, 72). Senator Klobuchar went through a painstaking process to detail rulings made by Sotomayor in which the average person would have sympathy for one side, but in which case the judge rules in favor of the other in accordance with the law (U.S. Senate 2009, 127-128).

The fact that the constituent referred to Sotomayor as "that woman" in a conversation with a woman senator, Klobuchar, shows that the framing of Sotomayor as 
an activist, empathetic Other was effective, to the point that a senator felt the need to use her time before the committee to publicly acknowledge and refute the constituent's concern. Sotomayor is unlike Klobuchar and other women, who are normal, reasoned, principled, restrained. Sotomayor, as "that woman," is a threat to the established order. It reveals the asymmetrical power balance that is given to the framework of the debate when it is confined to binarisms. Judicial restraint and solid, reasoned judicial decisions are the preferred path and anything Other than that is detrimental.

Using metaphors to reinforce binarisms

Aside from being replete with baseball analogies, which is a traditionally American and male dominated sport, the nomination hearings provided ample opportunity for other metaphors to manifest themselves. They served a useful purpose within the context of the nomination hearings to explain the position of Sotomayor as a judge within American society. For example, Senator Sessions, a Republican from Alabama, explained that without the limit of being "restrained by precedent and the threat of reversal from higher courts,” Judge Sotomayor's judicial philosophy, and by extension her latent activism, will be “allowed to reach full bloom” (U.S. Senate 2009, 7). Either this suggests that Sotomayor's full capacity as a judge is thus far restrained and will be able to grow into activism should she be confirmed to the Supreme Court, or it indicates a level of disingenuousness in her capacity as a judge. It suggests that as a judge she is not ruling in accordance with mainstream understandings of the law, but is instead playing a role in order to serve her own agenda. In this instance, that agenda is to be confirmed to the highest court in order to become unrestrained and thus unchained by things such as 
precedent and the threat of reversal from higher courts. In either case, the use of such a language device does not comport with Sotomayor's history as a judge for 17 years (U.S. Senate 2009, 123).

Metaphors are devices used to attribute a characteristic from one thing onto something else (Hegstrom and McCarl-Nielsen 2002, 220). But more importantly, metaphors serve as symbolic shortcuts. They serve the purpose of attributing deeper meaning to a subject indirectly. It allows the speaker to address the subject without directly confronting a particular aspect of that person. It is therefore able to accomplish the description of a thing using few words that otherwise would take a list of characteristics. It is in this capacity that we find the ability of Session's blooming metaphor to transmit larger meaning (Hegstrom and McCarl-Nielsen 2002, 223). A flower is used to describe a woman, which is common in American culture. It associates her with fragility, nature, beauty, softness, and delicateness (Hegstrom and McCarlNielsen 2002, 228). This reinforces a common double-standard, in which men are seen as rough and strong and women are soft and delicate. Men are hard-working and provide, while women are nurturing and take care of the home (Valenti 2008, 22-25).

Using a metaphor can also invoke stereotypes without their explicit mention. As Banaji and Hardin (1996) found, stereotypes can be invoked without explicit reference, with certain words or combinations of words used to serve as code for implicit gender roles. For example, certain occupations are explicitly gendered, like a fireman or waitress, but there are also implicitly gendered occupations, such as doctor and nurse. This is important because judgments are made based on gender roles automatically 
without explicitly acknowledging the gender. The English language is replete with gendered words and phrases, but this can be implicit as well as explicit (Banaji and Hardin 1996, 136, 141). So again, by utilizing the flower metaphor, the listener can be reminded about the implicit gender role of a judge, which is a position most commonly held by men.

It is in such comments that the underlying heterosexist conceptions of our governmental institutions are revealed. Language that appeals to the senses by using metaphors and invoking imagery associated with modesty, reproduction, growth, and sexuality, such as the idea of clothing nakedness and covering that which might offend, as well as comparing Judge Sotomayor to a flower not fully in bloom. Referencing a flower not fully bloomed is an unnecessary appeal to emphasize Sotomayor's gender, while using sexualized imagery to suggest that she might not be fully developed in her judicial philosophy or feign judicial modesty in a subversive attempt to obtain a higher position in government. By using such an appeal, the speaker is able to undermine the judge’s credibility, despite nearly two decades of experience, in order to question her motivations and highlight the risk associated with appointed a justice that is a woman by linking her with judicial activism (U.S. Senate 2009, 16).

By repeatedly mentioning the Wise Latina remarks (U.S. Senate 2009, 123), Republican senators effectively structured their argument against Sotomayor within the constraints of the judicial restraint/judicial activism and reason/desire binarisms. They highlight comments that suggest she might be an activist on the Supreme Court and has previously signaled a willingness to take into consideration identity as an influence in 
decision-making (U.S. Senate 2009, 425, 493). Such criticisms of Sotomayor's speech on the part of senators on the committee forced her to backtrack and apologize, calling the remarks a "rhetorical flourish that fell flat” (U.S. Senate 2009, 73). Advocates for her nomination on the committee came to her defense. Senator Durbin noted the context within which she spoke them. Senator Klobuchar mentioned that she made the controversial comments before her confirmation by the committee when nominated to the lower court and they went unnoticed or were not criticized back then. Senator Specter stated that people were making a "mountain out of a molehill” and noted the reference of other prior nominees to their life experience and background (U.S. Senate 2009, 144, 357, 373).

\section{Judicial restraint/judicial activism}

Democratic Senator Feingold tells viewers at the beginning of Sotomayor's nomination hearing to be wary of the term "activist,” as it often denotes a "a judge who decides a case in a way you don't like" (U.S. Senate 2009, 20). Senator Franken tells Sotomayor that he is concerned that "activism is on the rise," but he also states that he agrees with Feingold's definition, that often people use the term to describe a judge that rules in ways they do not like (U.S. Senate 2009, 53). Republican Senator Cornyn uses a different definition of activism in which he says it can be a good thing, "if it is enforcing the rights and the laws that have been passed by the legislative branch," but that it is a bad thing if it involves "inventing new rights" and "veering off this course of enforcing a written text" (U.S. Senate 2009, 33). This reinforces Gibson and Caldeira’s (2009) position that charges of judicial activism can complicate and obscure debates regarding a 
nominee's judicial qualifications, the following of stare decisis, and arguments based on policy and political ideology (Gibson and Caldeira 2009, 143).

While Democratic senators might be assuaged to know, as Senator Sessions tells Franken, that there can be conservative activists as well as liberal, it is the Republican senators that go on the assault against activism, which they appear to place on liberal judges (U.S. Senate 2009, 6). The Republican senators spend a significant amount of their time deriding activism and the judicial decisions made by activists in the judicial branch (U.S. Senate 2009, 22, 26-27, 33-34, 407, 425, 454). Democratic senators also subscribe to this framework of the debate, by ceding territory within the debate in emphasizing Sotomayor's judicial temperament and her modesty (U.S. Senate 2009, 14 24, 54-55, 77, 94, 127).

Sotomayor herself rejects the debate within the framework of activism versus restraint and instead characterizes constitutional questions and arguments regarding the law as having "no objective stance but only a series of perspectives. No neutrality, no escape from choice in judging" (U.S. Senate 2009, 122). However, Sotomayor’s position does not have to be acknowledged by the committee itself, which adheres to a view that places judging solely within the confines of a dichotomous relationship, between judicial restraint and activism.

\section{The Nomination of Elena Kagan to the United States Supreme Court}

Elena Kagan was nominated to be the fourth woman to serve on the United States Supreme Court in 2010 by President Obama. It marked President Obama's second nomination to the Court. She was selected to replace retiring liberal justice John Paul 
Stevens. Although she had no prior judicial experience, Kagan was dean of Harvard Law School and later the solicitor general for the United States (Baker 2010).

Not having prior judicial experience, but extensive academic experience in the area of the law, Kagan's nomination hearing focused on prominent issues within her tenure as dean at Harvard Law School. Primarily, emphasis was placed on her role as dean when military recruiters were prohibited from using the law schools facilities due to a conflict between the institution’s non-discrimination policy and the military's Don’t Ask Don’t Tell policy, which barred lesbians and gays from serving openly (Baker 2010). Republican senators pounced on this issue as an opportunity to show that Kagan did not adhere to the rule of law (Kagan 2010, Day 2, 60:00).

This issue area appeals directly to the binarisms identified by Burgess, such as heterosexuality versus homosexuality and judicial restraint versus activism. Calls for investigation into Kagan’s sexuality began on May 11, 2010, when the Wall Street Journal published an old photograph of Kagan playing softball on the front page of the paper (Appendix B). Although they did not explicit mention Kagan’s sexuality, other national newspapers capitalized on the appearance of the photo in the Wall Street Journal to initiate a debate regarding sexuality and the persistence of stereotypes (Fermino 2010).

The publication of the photo played upon assumptions and widely held stereotypes regarding the definition and appearance stereotypically associated with lesbians. By using a picture of Kagan playing softball, a women's sport that is also traditionally popular among lesbians, the Wall Street Journal was able to invoke a reaction. Other newspapers used it to begin debates regarding Kagan's sexuality as well 
(Fermino 2010; Washington 2010). Most of these played upon suspicion of violation of heterosexual norms. Besides Kagan's appearance, a softball player with short hair, she was also a successful professional with an academic career, middle-aged, unmarried, and without children (Washington 2010). It should be questioned as to why the appearance of a woman and how she compares to the appearance of other women has anything to do with her qualifications to hold a position within government, not to mention that is it the highly salient and respectable position of Supreme Court justice (King 1991, 3).

These characteristics played well together to allow Kagan to be criticized as a nominee in much the same way as Sotomayor. The characteristics of her as a nominee violated the traditional sexist interpretations regarding the role of women: that they marry a man and have children, instead of remaining single and pursuing a career (Burgess 1999, 203-204). The photograph of Kagan playing softball added another element to draw suspicion: that she might be homosexual. These factors placed her firmly within the outgroups established by normative constraints on governmental and social institutions. It also signifies a double standard, in which a woman's relationship status is deemed a valid point of discussion and pertinent in assessing her for a public position. The same scrutiny would not be afforded an unmarried male counterpart (Marcus 2010). While Roberts’ sexuality was discussed implicitly in the national media, it did not appear to gain traction (Scott 2005; Appendix C). A single, career professional woman without children was a threat to the order established in which men, the patriarchal heads of the family unit, are seen as the dominant authority figure (Butler 1990, 3, 39). 
In the context of these articles published in the national media, the nomination hearing for Kagan before the Senate Judiciary Committee is seen in a different light. While the senators do not explicitly acknowledge the photograph or question her sexuality, her opponents focus on issues which draw attention to her Otherness and as being a member of those outgroups in the dichotomous pairings: a woman, a judicial activist, and a homosexual or one that sympathizes with homosexuals. All of these, in combination, threaten the pre-established heteropatriarchal order (Burgess 1999, 204; LeMoncheck 1997, 38).

\section{Using words to reinforce binarisms}

Given that Kagan does not have the prior judicial experience like Sotomayor, senators had to review her written works, career history, and use their time during the hearings to investigate her judicial philosophy and temperament (Washington 2010). This appeared to be a problem for some of the senators, given that many of them lapsed in giving her deference in her position as dean of Harvard Law and Solicitor General of the United States. While Democratic Senators were consistent in referring to her as Dean or General Kagan, Republicans frequently referred to her as Miss Kagan, although not in every single instance (Kagan 2010).

While this in itself does not constitute sexualized language used to reinforce a Queer New Institutionalist approach to constitutional theory, it does contribute to the heterosexist conceptions of individuals. Men are given deference as they are usually called mister or assigned titles, such as senator, president, judge, etc. These are indications of accomplishment. Conversely, women are assigned titles based on their 
relationships to men (King 1991, 3, 46). By referring to her as Miss Kagan instead of General or Dean Kagan, it puts one more small emphasis on her position as a member of multiple outgroups and raises suspicions regarding her capacity to carry out her duties should she be confirmed as a justice (Crenshaw 2000). It continually reminds listeners that Kagan is single and has not conformed normatively by marrying a man and taking his last name.

\section{Using metaphors to reinforce binarisms}

Like during Sotomayor's nomination hearing, a number of metaphors were employed during Kagan’s nomination hearing before the Senate Judiciary Committee. Held in the summer of 2010, senators on the committee took turns to investigate Kagan's record to determine her fitness to serve on the highest court in the land. It marks an event in which the senators, as well as Americans, are able to get to know the president's nominee to the Supreme Court.

On the first day of the hearings, Republican Senator Sessions asks Kagan if, given her lack of experience, she is able to remain within the "harness of the law" (Kagan 2010, Day 1, 27:00). This, once again, is an appeal to the dichotomous relationship between restraint and activism in approaching constitutional theory. Sessions uses a simple metaphor to inquire as to Kagan's fidelity and adherence to the law, a refutation of judicial activism, and operations within the confines he expects of a nominee to the Supreme Court. It is misleading to the inquiry as to Kagan’s judicial philosophy because it subscribes to an objective reading of the Constitution, one which does not exist. Justices are not democratically elected and are instead appointed by the President. They 
are removed from the electorate and are therefore given no direct mandate from the country’s citizens (Burgess 1999, 205; U.S. Senate 2009, 463; Gibson and Caldeira 2009, 142).

Sessions' metaphor again evokes a contrast between the heterosexist norm that is preferred and the candidate presented before the committee: Kagan. As a single woman, focused on her career, she is not conforming to the expected role attributed to women in our society. As an individual outside the confines of the patriarchal family, she is thus marginalized (Burgess 1999, 204). Also, as not having a prior role as a judge, senators have to rely on her professional writings and career as an academic and solicitor general in order to assess her judiciousness and political ideology (Gibson and Caldeira 2009, 140). By asking how Kagan would operate within the confines, or the "harness," of the law, the senator subscribed to stereotypes and assumptions argued by a Queer New Institutionalist approach. He could have asked what reason he had to believe that Kagan would not operate within the confines of the law, instead of the opposite.

Other metaphors were utilized by opponents during Kagan’s nomination hearing. On the last day of the hearings before the committee, witnesses were called to present their support or opposition to the nominee publicly before the committee. The individuals, many of whom represent interest groups and political organizations, submit their comments for the records and also answer questions posed by the senators on the committee. Compared to the opinions expressed by the senators regarding the nominee, the statements made by witnesses before the committee are much more aggressive, pointed, and politically adversarial (Kagan 2010, Day 4). 
One such witness for the minority Republicans on the committee was Robert Alt from the Heritage Foundation. In his comments before the committee, he assailed Kagan. Alt speaks out against liberal activism, which he distinguishes from conservative activism. He argues that the Supreme Court's decision in Citizens United case was activism which overturned precedent, but which returned to an even older precedent. This is opposed to the Court's decision in Austin v. Chamber of Commerce. In his characterization, that was an instance of liberal activism in which the Court embraced speech equalization theory which ignored precedent in a way incomparable to the Citizens United ruling (Kagan 2010, Day 4, 130:00).

While Alt's testimony is a more general critique of activism in general, specifically liberal activism, he links it in the end to the nomination of Kagan, who he suggests would be another member of the liberal wing of the Court, ready to overturn historic precedent. No such instances of explicit sexualized language were used by witnesses testifying against Sotomayor (U.S. Senate 2009). By utilizing sexualized language, he is able to manipulate imagery that is threatening to the average human being. An “orphaned eunuch,” as he describes the legislation after the ruling from a liberal activist court, is one which cannot reproduce and lacks the capability to fend for itself (Kagan 2010, Day 4, 130:00). Without parents, an orphan is alone in the world and vulnerable. The imagery of a eunuch suggests castration, which is a threat to the reestablished conception of society, where the patriarchal family is the basic unit. The assumed dominance of men is thus threatened by such an activist Court. With its liberal 
agenda, it can lash out at that which it sees as detrimental to society and remove its ability to reproduce, thereby rendering it useless and invalid.

Judicial restraint/judicial activism

The focus on the issue of the military's Don’t Ask Don’t Tell (DADT) and additional questions on the possible legal future for the Defense of Marriage Act (DOMA), demonstrate further attempts to frame the debate within the confines of heterosexual versus homosexual and judicial restraint versus judicial activism dichotomies. By focusing on issues that deal with homosexuality, senators are able to indirectly remind Americans about the questions previously raised regarding the speculation about Kagan’s sexuality while also dealing with possible upcoming issues (Kagan 2010, Day 3, 168:00, 336:00, 394:00). These issues are ones that are able to fit well within the confines of the debate between activism and restraint. Since public opinion on questions regarding homosexuality continue to evolve, and it is probable that at least one of them will come before the Court, they serve as the perfect area of focus for opponents. If Kagan has already been the subject of suspicion raised in national newspapers over her sexuality, then attempts to characterize her as a judicial activist in regards to issues of homosexuality could prove beneficial to her opponents.

Such charges of activism again provoke her defenders, Democrats on the committee, to come to her aid. Senator Schumer notes also that she is "judicially modest" (Kagan 2010, Day 2, 439:00). Kagan herself talks about having restraint and humility during the hearing. Senator Kyl asks Kagan if she can be a neutral arbiter, which again suggests that he has reason to believe that so far she is not or has not been neutral in her 
approach to the law (Kagan 2010, Day 1, 82:30). Senator Graham asks if her "activism can be parked” (Kagan 2010, Day 1, 99:20). While he may be referring to her role as the “advocate” for the government's position as the solicitor general, it might also suggest that he does not necessarily expect her to be restrained. This is directly within the confines of the restraint versus activism debate. Multiple senators cast doubts over Kagan's ability to adhere to the Constitution and the law by characterizing her as unrestrained, unable to approach the law in an unbiased fashion. So from a position in which she came into the hearings under suspicious and scrutiny of the public eye for her identity or what her identity was expected to be, Kagan continued to be criticized and judged harshly as one who would violate the constraints of the system; she would reject restraint in judging and instead work as an activist.

The debates during Kagan’s nomination hearing are therefore place firmly within the theoretical confines of the judicial restraint versus activism binarism. Even Kagan allows this construction of the debate regarding constitutional theory to be maintained. At one point during the hearing, Democratic Senator Whitehouse mentions the rise in 5-4 decisions on the Supreme Court. He cites this as evidence that the Court is divided and that judges follow their own personal policy preferences. He is refuted by Kagan herself. She explains that it means justices have honest disagreements about the law and that it is not indicative of personal preferences being followed. (Kagan 2010, Day 3, 32:00).

Perhaps it is easier for Kagan to refute Whitehouse than acknowledge an argument outside the simple constraints of the restraint versus activism dichotomous pairing. She does not have a judicial record, not having previously served as a judge, and 
therefore can refute suggestions that she is an activist as there is no prior proof. Instead of having to defend an alternate conception of constitutional theory or how the justices on the Supreme Court reach their decisions, she can deflect criticism by using her own record and history to refute criticism within the confines of the restraint versus activism frame, even if it is flawed in practice (Burgess 1999, 204-205).

The confirmation hearings for Sotomayor and Kagan to the Supreme Court during the $111^{\text {th }}$ Congress focused on controversial issues from their past. Sotomayor was charged with being an activist, as charged by Senators citing her Wise Latina comments and ruling in the Ricci case. This helped reinforce male/female, white/non-white, reason/desire, and judicial restraint/judicial activism binarisms in attempts to raise suspicions and associate her with the marginalized Other. Kagan faced questions from opponents regarding her history as Dean of Harvard Law and policies implemented to challenge Don’t Ask Don’t Tell and the Solomon Amendment. This appeals to the constraints imposed by male/female, reason/desire, heterosexual/homosexual, and judicial restraint/judicial activism binarisms. It too was used to cast doubt on the nominee as to her judicial fitness to represent preconceived norms regarding society and governmental institutions. Specifically, questions were raised about the fitness of the nominees to conform to the expected heteropatriarchal standards necessary to serve as Supreme Court justices (U.S. Senate 2009; Kagan 2010; Sedgwick 10-11; Burgess 1999, 207-217). 


\section{Results and discussion}

\section{Results}

There is no doubt that Supreme Court nomination hearings are partisan affairs. Congress is a political body, and the nominees are selected by the president, and therefore it is to be expected that Republican presidents are likely to nominate conservative judges to the Court and Democratic presidents are likely to nominate liberal justices. After reviewing the nomination hearings of the four most recently appointed Supreme Court justices, the pattern established by Gibson and Caldiera (2009). According to the authors, nominees are examined to see if they have the professional qualifications to serve on the highest court in the land. Their records and judicial temperament is also probed to determine if it falls within the mainstream of American politics $(140,143)$.

Gibson and Caldiera found that during Alito’s nomination hearing, the nominee focused on his judicial qualifications and downplayed political issues in order to secure confirmation (144). This was also true of Roberts, Sotomayor, and Kagan. As they explain, charges of “judicial activism” can complicate the proceedings, and this was true of the nominees before the Senate Judiciary Committee during the $109^{\text {th }}$ and $111^{\text {th }}$ Congresses. While all four of the nominees receiving confirmation from the entire Senate, this was not without having to endure criticism and inflation of possible controversies (Gibson and Caldiera 139, 141; Savage 2009; Baker 2010).

What happens in the nomination hearings does not occur within a vacuum. The senators submit for the record editorials from prominent newspapers during the hearings. This suggests that they are receptive to the commentary circulating on the Hill as the 
nomination proceeds. Thus, one must be alert to these narratives that might arise in the outside media, as they may produce an indirect influence on the hearings themselves. Senators may be prompted by revelations in the media to initiate a line of questioning that, observed in isolation, could be taken at face value and not extend to a secondary meaning that referenced the outside sources pressuring particular committee members to pursue certain inquiries.

Double standards

Roberts and Alito, two married white men, were appointed by a Republican president and confirmed by a Republican Senate. Conversely, Sotomayor and Kagan, a Hispanic woman and a white woman, both single, were appointed by a Democratic president and confirmed by a Democratic Senate. Applying the theory of Queer New Institutionalism allows for a critical examination of the implications and effects of reinforcing binarisms. Dichotomous pairings represent asymmetrical power balances that are inherently unstable (Sedgwick 1990, 10; Burgess 1999, 200-201). If the prescription of Queer New Institutionalism is to be proven correct, then the reinforcement of binarisms will occur regardless of the political leanings of the individuals involved. Republican senators utilize them in the nomination hearings of conservative nominees to the Court, just as likely as Democratic senators use them in the nomination hearings of liberal nominees. This has been demonstrated in an analysis of the nomination hearings for Roberts, Alito, Sotomayor, and Kagan. The maintenance of binarisms occurred regardless of party identification of the senators on the committee or the nominee before them. 
The implications for the nominees were quite different when comparing those of the $109^{\text {th }}$ Congress, Roberts and Alito, and those of the $111^{\text {th }}$ Congress, Sotomayor and Kagan. Conspicuously absent from the nomination hearings of Roberts or Alito are any mention of the potential that their judicial philosophies could be allowed to "bloom" if appointed to the Supreme Court. There is no mention of “orphaned eunuchs” (U.S. Senate 2005; U.S. Senate 2006). And although the New York Times implied it, no significant tests of Roberts' sexual orientation migrated to the nomination hearing itself (Scott 2005). However, questions about Kagan’s sexuality and the subsequent focus on issues relevant to LGBT equality were central controversies during her confirmation hearings (Appendices B, C).

Questions regarding Roberts’ sexuality were in the form of a photograph published in the New York Times, coupled with the comparison of his association with conservatives at Harvard with queers as marginalized Others, apparently never gained traction. This is probably due to the fact that he is married and his wife and kids were present during his confirmation hearing (U.S. Senate 2005, 1). This reinforces Sedgwick's point in realizing that the binary pairs allow for the creation of identity and not just action. It does not matter who Roberts is attracted to and what sex he engages in, because he conforms to (most) heteropreferential ideals. He is married (even though it occurred later in life) and he has children (even though they were adopted). However, the suspicion associated with Kagan’s nomination and her potential to be a lesbian was more blatant and enduring. After a photo of her playing softball was published in the Wall 
Street Journal (Appendix B), other major newspapers ran with the theme in more explicit terms.

The New York Post reran the picture with the headline, "Does this photo suggest high court nominee Elena Kagan is a lesbian?” (Fermino 2010). It does not matter what the content of the article said after that leading condemnation. The closet door is thus opened, and regardless as to whether or not Kagan is in there, the suspicion remains. The Chicago Sun Times was more accurate with its headline, "Stereotypes spur question on Kagan” (Washington 2010). Still, it is unfair to pose such a question for a number of reasons.

Rumors, gossip, and suggestive innuendo regarding the sexual orientation of Supreme Court nominees proved to be a sexist endeavor, showing preferential treatment to heterosexual norms. While these questions of sexuality were raised in regards to Kagan and Roberts, they did not persist in the same ways. Roberts was a married man with children, therefore suspicion that he was gay subsided. This is despite photographic evidence of him holding a pie in the 1980s. However, since Kagan is a single woman in her 50s, a photograph of her enjoying softball in the 1990s allows questions of her sexuality to persist (Scott 2005; Fermino 2010). It is a persistent suspicion that continues to present day. Google searches for the names of each of the nominees reveal the top searches for Kagan to include "Elena Kagan gay” and "Elena Kagan husband.” The same is not true for the single Justice Sotomayor, who is of a similar age, and Chief Justice Roberts, whose sexuality was questioned as well, or for the married Justice Alito (Appendix C). 
An unfair assumption based on stereotypes regarding Kagan’s sexuality is also suggestive of other factors predicted by Queer New Institutionalism, as demonstrated in the discourse analysis during her nomination hearing. If she is an unmarried woman who has focuses and been successful in her career, and if she enjoys softball, she must be a lesbian. If she is a lesbian and was appointed by Democratic president, she must be politically liberal and therefore a judicial activist. If she is a judicial activist and if Don't Ask Don’t Tell policy was an issue during her tenure as Dean at Harvard Law, she will rule based on her personal policy preferences which means a bias towards people like her (read: homosexuals). If she is biased towards her personal preferences, she will legalize same-sex marriage, and so forth. By utilizing one photograph and running it on the front page of a major American newspaper, shortcut stereotypes can lead to prejudgments and prejudices based on heteropreferential norms (Fermino 2010, Washington 2010).

It is through this subtle crescendo that builds over time that witnesses before the Senate Judiciary Committee are then justified in charging that the appointment of a justice just as Kagan will lead to legislation comparable to an “orphaned eunuch.” Even though Kagan had never been a judge, she apparently has the motivation. The only thing missing is her ascension to a liberal Supreme Court full of judicial activists to provide her with the weapon she needs to castrate legislation and threaten the stability of heteropatriarchal society (Kagan 2010, day 4, 1:30:00).

While hyperbolic, it was the choice of sexualized language used by the witness, Robert Alt of the Heritage Foundation, to deride and hopefully derail the appointment of Kagan to the Supreme Court. To be fair, usage of such language resulted in scoffs and 
smirks from the people in the committee hearing room, as is visible in the video records of the proceedings (Kagan 2010, day 4, 1:30:00). While colorful language in the extreme, it illustrates the point made by all the rumors, gossip, and innuendo evident in the circumlocution by some media outlets and the senators in their line of questioning. It also served to reinforce the binarisms identified by Queer New Institutionalism.

Binarisms: a product of partisanship?

By using Queer New Institutionalism as the basis to studying Supreme Court nominations, reinforced norms based on sexuality are identified and challenged. The theoretical constructs which maintain these norms, binarisms, waver and the lines drawn by them are blurred once under critical examination. This was demonstrated through Senator Brownback’s appeal in both the Roberts and Alito nomination hearings to ignore repeated precedent and overturn Roe v. Wade.

The nomination hearings are replete with reference to heteronormative behavior. This is most notable in the continual dependence on baseball analogies. A male dominated sport, it is America’s pastime. The majority wants a justice that will exercise judicial restraint and will use neutral principles to reach objective decisions. It wants an umpire to call balls and strikes. It wants a reasoned, judicially restrained, straight, white, male. Not an umpire that will walk out onto the field and start playing the game for themselves. Nor does it want a queer. Or an ethnic/racial minority. Or a woman. That is the essence of the demands of the dichotomous pairings uncovered by a Queer New Instititonalist approach, if they are allowed to remain unchallenged. 
The victims of these binarisms are the nominees themselves, as senators, witnesses, and the media work to constrain them within the confines of the dichotomous pairings. Using the association with the minoritized Other to raise suspicion in the hopes of derailing the nominee in favor of one more in line with their policy preferences. The nominees were forced, at times, to operate within the confines of the binarisms. Roberts appealed to neutral principles, aligning himself with the dominant sphere of judicial restraint in the face of the minoritized judicial activism. Alito accepted Hatch's assertions at the prevalence of judicial activism, responding that justices needed to be restrained. Sotomayor disavowed her Wise Latina comments as a "rhetorical flourish that fell flat" instead of trying to justify them. Kagan agreed that judicial restraint was needed in the face of increasing activism. These binarisms were referenced by senators of both parties. In comments his comments during Sotomayor's nomination hearing, Franken says he favors judicial restraint but is worried that activism is on the rise (U.S. Senate 2009, 53).

However, not all of the nominees subscribe to these dichotomous views. Although Sotomayor is forced to retreat from and downplay her Wise Latina comments, senators also criticize her for admitting that she believes there is "no objective stance but only a series of perspectives.” Senator Kyl uses her position in combination with his critique of her Wise Latina comments to suggest she will use identity and desire, rejecting restraint and reason, in her decision making. To refute this, Sotomayor depends on her record as a judge. Despite comments that she made during various speeches, she has a judicial record of 17 years to defend her position that she is a judge that adequately applies the law (U.S. Senate 2009, 122-123). 
While sexualized language is used to reinforce binarisms, it was also used to refute them, as Senator Specter did in using his term "flaming liberal" to offset the "arch conservative.” He used the terms in reference to Alito, suggesting that if one had an agenda to paint him as a judge one way or another, they would only need to be selective in the cases they wish to use to demonstrate it. Specter uses the contrasting pairs to denounce a perception of Alito that would place him resolutely in either category. By using this language, he is simultaneously acknowledging the persistence of the binarism, and also similar ones, and denouncing them as well.

Judicial restraint/judicial activism: to the exclusion of alternative approaches

It might be plausible to blame the nominees for allowing the dichotomous constraints outlined by Burgess (1999) and Sedgwick (1990) to endure. Sotomayor was refuted by Senator Kyl for stating that there is no objective stance to interpret the Constitution (U.S. Senate 2009, 122). But even when senators themselves raise the possibility that there is no objective stance, the nominees refute them.

Senator Whitehouse tried to raise the point that by noting an increase in 5-4 decisions released by the Supreme Court, mirroring the findings of Epstein and Knight (1998) during Kagan’s nomination hearing. Kagan refuted his point and insisted that judges do not make decisions based on their personal policy preferences as the academic research suggests. Sotomayor and Alito both state that reasonable people can disagree when presented with a set of facts, even judges (U.S. Senate 2006, 332; U.S. Senate 2009, 131). 
The increasing lack of consensus should make a reasonable citizen suspicious of this explanation for the prevalence of split decisions from the Court, if only for the fact that academic studies which attempt to explain how the Supreme Court justices operate are thorough and convincing in their analysis and evidence. But the prerogative of the nominees and justices to ignore such studies, such as Epstein and Knight’s (1998), may insulate the Court and protect it from unnecessary criticism. However, this does a disservice to American citizens who are removed from the Supreme Court. As an unelected body removed from the democratic process, failure to refute the binarisms reinforces the status quo (Burgess 1999, 205, 214). This is the same status quo that is biased towards the dominant groups maintained by the previously identified dichotomous pairings. It is the same status quo that seeks to keep the minoritized Others out of the mainstream.

As Burgess predicted, a Queer New Institutionalist perspective will reveal the logical inconsistencies once the theoretical binarisms are applied to the practical. This occurred during Sotomayor's nomination hearing, when her responses prompted Senator Graham to suggest she was beginning to sound like a strict constructionist (U.S. Senate 2009, 135). By continually reinforcing the constraints of dichotomous pairs, namely judicial restraint/judicial activism, the senators received responses cast in that mold. Graham exhibited frustration with Sotomayor's responses, perceiving them to be much like what would be expected from a strict constructionist. This indicates that he perceives that she is not a strict constructionist in reality. Sotomayor also disavowed the implications of her Wise Latina comments and reluctance to further develop her prior 
comments about the lack of an objective stance in interpreting the Constitution (Sotomayor 2009, 122-123). She fails to identify or develop an alternative outside the established binarism of judicial activism/judicial restraint. The only available options are for Sotomayor to respond to questions during the hearings in a way that appeals to the senators seeking a judicially restrained jurist, or admitting to being a judicial activist which would likely lead to rejection to the Court by the Senate. As predicted by Queer New Institutionalism, the binarism forces an "intellectual impasse" to the detriment of those that are served by the system, the citizens (Burgess 1999, 214).

There is also no indication that judges are not testifying honestly when they refuse to openly reject the status quo that reinforces those binarisms. For example, during his nomination hearing, Roberts rejects academic analyses. He tells Senator Grassley that he believes judging in accordance with the rule of law follows a more "pragmatic" approach, to the detriment of academic theories, stating that their "demands and nuances... are dispensed with fairly quickly” (U.S. Senate 2005, 182). This is a view that has persisted with Roberts even after he secured confirmation as Chief Justice. In a recent interview with Supreme Court justices regarding legal writing, Roberts stated, "what the academy is doing, as far as I can tell, is largely of no use or interest to people who actually practice law” (Liptak 2011). For Chief Justice Roberts, at the very least, there is no need to stop operating from the confines of the judicial restraint/judicial activism binarism, as he remains a part of the dominant spheres identified by binarisms. Implications for women and minorities 
Times have changed, and the status quo has evolved. Women do not have to act within the constraints of outdated norms, as evidenced by the increase in female attorneys and female judges and justices in the federal judiciary (U.S. Senate 2009, 561). The persistence of binarisms, as identified by Queer New Institutionalism, shows that there are invisible influences which attempt to impose the default assumptions and dominance associated with certain groups, at the expense of outgroups. This was acknowledged through the analysis of various behaviors throughout the nomination hearings.

Although it is a horrible insult to women to imply their inferiority for a variety of reasons, accepting the format and structure of the nomination hearings as is does nothing to refute the constraints of women as being members of a marginalized outgroup. However, it could be argued that it serves women and associated outgroups to tolerate the power structures at work within the nomination hearings, because if they are confirmed, members of such outgroups will have attained a position where they can do more relative good as compared to the relative injustice done by reinforcing stereotypes and assumptions directed to the nominees through questioning. But, this would confirm the suspicions of members of the committee, who speculate that nominees answer questions in accordance with the expectations of the committee, merely to obtain confirmation. Evidence of this would then confirm to those that support the confining binarisms to continue to employ them to constrain normative behaviors.

Many of the actors involved in the hearing process signaled a frustration with the disingenuous nature of the proceedings: they do not seem to reflect reality outside the Hart office building where the hearings are held. Several senators, such as Schumer and 
Graham made comments during the hearings signaling their frustration with questions going unanswered and nominees being vague, hedging, and obscuring their actual political opinions on several issues (U.S. Senate 2005, 375; U.S. Senate 2006, 38; U.S. Senate 2009, 135-136).

\section{Conclusion}

Approaching Supreme Court nomination hearings from a Queer New Institutionalist perspective provides the opportunity to look at such events through a lense that does not take underlying themes of sexuality and desire for granted. These themes serve as the basis for our society and institutions (Burgess 1999, 200). By locating and deconstructing the binarisms identified by queer theory, the theoretical constraints they reinforce can then be applied in practical terms. They reflect an untenable power imbalance, in which dominant ingroups rely on subordinate outgroups to maintain order. This power asymmetry is unstable and bound to collapse. This is because of the inevitability of individuals who will arise that are unable to be categorized and confined by the preestablished binary pairs. The marginalized Other cannot be removed, and the dominant spheres rely upon such individuals for their survival. For example, without the homosexual there is no heterosexual identity. It is entirely dependent upon the existence of the marginalized homosexual identity (Sedgwick 1990, 10; Butler 1990, 39).

When viewed in the pragmatic political forum of Supreme Court nomination hearings, these dichotomous pairings fail, such as judicial restraint/judicial activism, male/female, white/black, heterosexual/homosexual, democratic authority/individual rights, reason/desire, etc (Burgess 1999, 204, 208, 217). Utilizing discourse analysis, the 
four most recent nomination hearings for Supreme Court justices were deconstructed to identify the use of such constraints to reinforce preferred heteropatriarchal norms. The identified dichotomous pairings reflect a default preference for dominant spheres of influence. This acceptance of the mainstream position of the dominant spheres as ingroups is challenged when under close examination.

The Supreme Court nomination hearings studied provided prime examples of how the maintenance of heteropreferential norms proves unworkable. While appealing for adherence to judicial restraint, senators needed to rely on the existence of judicial activists in order to maintain the dichotomous relationship between the two. In the apparent absence of such a marginalized Other, such as during the confirmation hearing of Judge Alito, proponents were left without a focus and were thus forced to skirt the line between the binarism. Republican senators, such as Brownback, who had previously appealed and reinforced judicial restraint, were suddenly emotionally appealing for their desire for an activist judge to enact his personal policy preference and overturn precedent in overruling Roe v. Wade (U.S. Senate 2006, 462-464).

These binarisms fail to predict in the face of marginalized Others, who will always arise (Butler 1990, 39), whether it is in the form of a white, male, conservative senator expressing his desire to enact his personal policy preferences, or a single, female, Supreme Court justice that fails to define herself within the construct of judicial restraint/judicial activism. The failure of such binarisms to persist in practical terms means that, in reference to the Supreme Court, senators will need to find new ways in which to investigate the judicial temperament of nominees. 
But the persistent reinforcement of these norms may cause inaction just as much as action. The president must choose a nominee that will pass confirmation by the Senate. Further exploration into the decision-making of the executive would add strength to the theory. If the president considers, but is reluctant, to nominate a justice who can overwhelmingly be framed as a marginalized Other within the context of identified binary pairings, Senators will be successful in continuing to frame the debate in such a manner. It would prevent nominees that raise suspicions as not conforming to normative expectations from ever being considered.

By looking beyond the identities of potential nominees, assumptions based on appearances and superficial appeals to heteropatriarchal norms can be rejected in search of their perspective regarding the Constitution. As an unelected, undemocratic body, the Supreme Court rules over constitutional issues that affect all Americans (Burgess 1999, 205). It is the Senate's duty to “advise and consent” in order to determine the judicial philosophy and fitness of the president's nominees (U.S. Constitution, art. 2, sec. 2). By rejecting the constraints of established binarisms, the Senate can move closer to a critical examination of nominees that is more satisfactory, accountable to the electorate, and intellectually honest. 
Works cited

Alvesson, Mats, and Kaj Sköldberg. Reflexive Methodology: New Vistas for Qualitative Research. Los Angeles: SAGE, 2009.

Baker, Peter. 2010. Kagan Is Sworn In as the Fourth Woman, and 112th Justice, on the Supreme Court. New York Times, late edition. 8 August.

Banaji, Mahzarin, and Curtis Hardin. 1996. "Automatic Stereotyping." Psychological Science. 7, no. 3: 136-141.

Berger, Peter L., and Thomas Luckmann. The Social Construction of Reality; A Treatise in the Sociology of Knowledge. Garden City, N.Y.: Doubleday, 1966.

Burgess, Susan. “Queer New Institutionalism: Notes on the Naked Power Organ in Mainstream Constitutional Theory and Law.” In The Supreme Court in American Politics: New Institutionalist Interpretations, edited by Howard Gillman and Cornell W. Clayton. Lawrence, Kan: University Press of Kansas, 1999.

Butler, Judith. Gender Trouble: Feminism and the Subversion of Identity. New York: Routledge, 1990.

Crenshaw, Kimberlé. "Demarginalizing the Intersection of Race and Sex: A Black Feminist Critique of Antidiscrimination Doctrine, Feminist Theory and Antiracist Politics." In The Black Feminist Reader, edited by Joy James and T. Denean Sharpley-Whiting. Malden, Mass: Blackwell Publishers, 2000.

Epstein, Lee, and Jack Knight. The Choices Justices Make. Washington, D.C.: CQ Press, 1998. 
Fermino, Jennifer. 2010. Does This Photo Suggest High Court Nominee Elena Kagan is a Lesbian? New York Post. May 13.

Gee, James Paul. An Introduction to Discourse Analysis: Theory and Method. London: Routledge, 1999.

Geer, James H., and Jeffrey S. Melton. 1997. "Sexual Content-Induced Delay With Double-Entendre Words." Archives of Sexual Behavior. 26, no. 3: 295-316. Gibson J.L., and Caldeira G.A. 2009. "Confirmation Politics and the Legitimacy of the U.S. Supreme Court: Institutional Loyalty, Positivity Bias, and the Alito Nomination." American Journal of Political Science. 53, no. 1: 139-155.

Gillman, Howard, and Cornell W. Clayton. The Supreme Court in American Politics: New Institutionalist Interpretations. Lawrence, Kan: University Press of Kansas, 1999.

Hegstrom, Jane L., and Joyce McCarl-Nielsen. 2002. "Gender and Metaphor:

Descriptions of Familiar Persons." Discourse Processes. 33, no. 3: 219-234.

Irving C.J., and English L.M. 2008. "Partnering for Research: A Critical Discourse Analysis." Studies in Continuing Education. 30, no. 2: 107-118.

Jagose, Annamarie. Queer Theory: An Introduction. New York: New York University Press, 1996.

King, Ruth Elizabeth. Talking Gender: A Guide to Nonsexist Communication. Toronto: Copp Clark Pitman, 1991.

LeMoncheck, Linda. Loose Women, Lecherous Men: A Feminist Philosophy of Sex. New York: Oxford University Press, 1997. 
Liptak, Adam. 2011. Keep the Briefs Brief, Literary Justices Advise. New York Times, online edition. May 20. http://www.nytimes.com/2011/05/21/us/politics/21court.html?_r=1\&pagewanted =1\&partner=rss\&emc=rss (accessed May 21, 2011).

MacKinnon, Catharine A. Women's Lives, Men's Laws. Cambridge, Mass: Belknap Press of Harvard University Press, 2005.

Marcus, Ruth. 2010. Smart women, fewer choices. Washington Post, regional edition. May 14.

Markon, Jerry. 2009. Uncommon Detail Marks Rulings by Sotomayor; She Almost Oversteps Her Role, Experts Say. Washington Post, met 2 edition. July 9.

Martel, Angeline and Linda Peterat. "Sexism in Naming the World: Consciousness in a Patriarchal Iceberg” In Taking Sex into Account: The Policy Consequences of Sexist Research, edited by Jill McCalla Vickers Ottawa, Canada: Carleton University Press, 1984.

McElhinny, Bonnie. “Language, Sexuality and Political Economy.” In Language and Sexuality: Contesting Meaning in Theory and Practice, edited by Kathryn Campbell-Kibler. Stanford, Calif: Center for the Study of Language and Information, 2002.

Nixon, Ron. 2009. Sotomayor’s Judicial Impartiality a Likely Focus for Hearings. New York Times, late edition. July 13.

Potter, Jonathan, and Margaret Wetherell. Discourse and Social Psychology: Beyond Attitudes and Behaviour. London: Sage Publications, 1987. 
Sager, Lawrence G. Justice in Plainclothes: A Theory of American Constitutional Practice. New Haven, CT: Yale University, 2004.

Savage, Charlie. 2009. Senate Confirms Sotomayor for the Supreme Court. New York Times, late edition. August 7.

Schuck, Peter H. and the Ralph Nader Congress Project. The Judiciary Committees: A Study of the House and Senate Judiciary Committees. New York: Grossman Publishers, 1975.

Scott, Janny. 2005. Roberts’s Harvard Roots: A Movement Was Stirring. New York Times, online edition. 21 August. http://www.nytimes.com/2005/08/21/politics/politicsspecial1/21harvard.html?pag ewanted=1\&ei=5094\&en=f89624daad372b3f\&hp\&ex=1124596800\&partner=ho mepage (accessed May 22, 2011).

Sedgwick, Eve Kosofsky. Epistemology of the Closet. Berkeley: University of California Press, 1990.

United States Senate Committee on the Judiciary. http://judiciary.senate.gov/ (accessed March-May, 2011).

U.S. Congress. Senate. Committee on the Judiciary. 2005. Confirmation Hearing on the Nomination of John G. Roberts, Jr. to be an Associate Justice of the Supreme Court of the United States. 109th Cong., 1st sess., September 12-15.

U.S. Congress. Senate. Committee on the Judiciary. 2006. Confirmation Hearing on the Nomination of Samuel A. Alito, Jr. to be an Associate Justice of the Supreme Court of the United States. 109th Cong., 2nd sess., January 9-13. 
U.S. Congress. Senate. Committee on the Judiciary. 2009. Confirmation Hearing on the Nomination of Hon. Sonia Sotomayor, to be an Associate Justice of the Supreme Court of the United States. 111th Cong., 1st sess., July 13-16.

Valenti, Jessica. He's a Stud, She's a Slut and 49 Other Double Standards Every Woman Should Know. Berkeley, CA: Seal Press, 2008.

Washington, Laura. 2010. Stereotypes spur question on Kagan. Chicago Sun Times, final edition. May 17.

Wechsler, Herbert. 1959. "Toward Neutral Principles of Constitutional Law." Harvard Law Review. 73, no. 1: 1-35.

Widdowson, H. G. 1998. "Readings in Critical Discourse Analysis; N. Fairclough: Critical Discourse Analysis; R. Hodge and G. Kress: Language As Ideology. Second Edition." Applied Linguistics. 19, no. 1: 136.

Wing, Adrien Katherine. Critical Race Feminism: A Reader. New York: New York University Press, 1997. 
Appendix A. Controversial Roberts Photo

Accessed on May 22, 2011.

\section{Roberts's Harvard Roots: A Movement Was}

Stirring

\section{By JANNY SCOTT}

Published: August 21, 2005

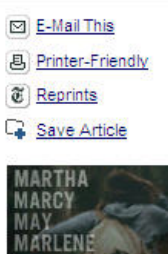

Correction Appended

John G. Roberts Jr. arrived at Harvard in the fall of 1973, a nascent conservative from a Catholic boarding school in the Republican Midwest, transplanted to Cambridge, Mass., at a time when campus conservatism seemed to be in hibernation. Prep school Marxists blustered about armed struggle, and students picketed liquor stores for carrying a boycotted wine Conservatives were casually dismissed as a joke.

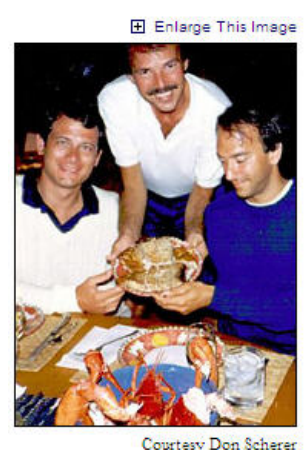

Courtesy Don Scherer John G. Roberts Jr., President Bush's Supreme Court nominee, and Harvard classmates Don Scherer, center, and Richard Lazarus on Martha's Vineyard in the 1980's.

SUPREME COURT IN TRANSITION

- go to complete coverage increasingly influential; and Grover G. Norquist, who was a class behind Mr. Roberts in college and is president of Americans for Tax Reform and a major figure behind Mr. Bush's tax cuts.

Judge Roberts, President Bush's Supreme Court nominee, spent the next six years at Harvard and Harvard Law after Watergate and before the election of President Ronald Reagan -when it was almost possible to graduate from Harvard without ever

encountering a card-carrying conservative in a seminar or a dining hall or having seriously to confront a conservative position.

"Conservatives were like the queers on campus," said Eric Rofes, a classmate of Judge Roberts who later became an organizer on gay issues. "People made fun of them. They mocked them and saw them as jokers or losers. I don't think in the moment many people realized this was the start of an ascending movement. People felt it was like the last cry of the 1950 's."

In fact, a striking number among the small cluster of conservatives at Harvard in Mr. Roberts's era went on to become important figures in the conservative resurgence, which began gaining momentum around the time of the 1980 election. Some of them now say that being a part of that often ridiculed minority left them with skills that have been essential in their movement's subsequent success.

The group includes Spencer Abraham, a law school contemporary and former secretary of energy under President Bush who helped found the Federalist Society, a conservative legal group seen as . Bus's tax cuts. 
Appendix B. Controversial Kagan Photo

Accessed on May 4, 2011.

\section{THE WALL STREET JOURNAL.}

Dougonses

$\ldots \ldots$

TUE SDAY, MAY U, 2010 - VOL. CCLY NO. 100

$\star \star \star \star \star \$ 2.06$

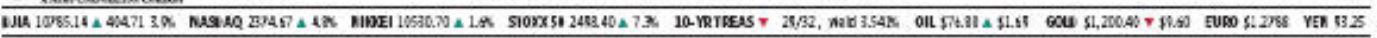

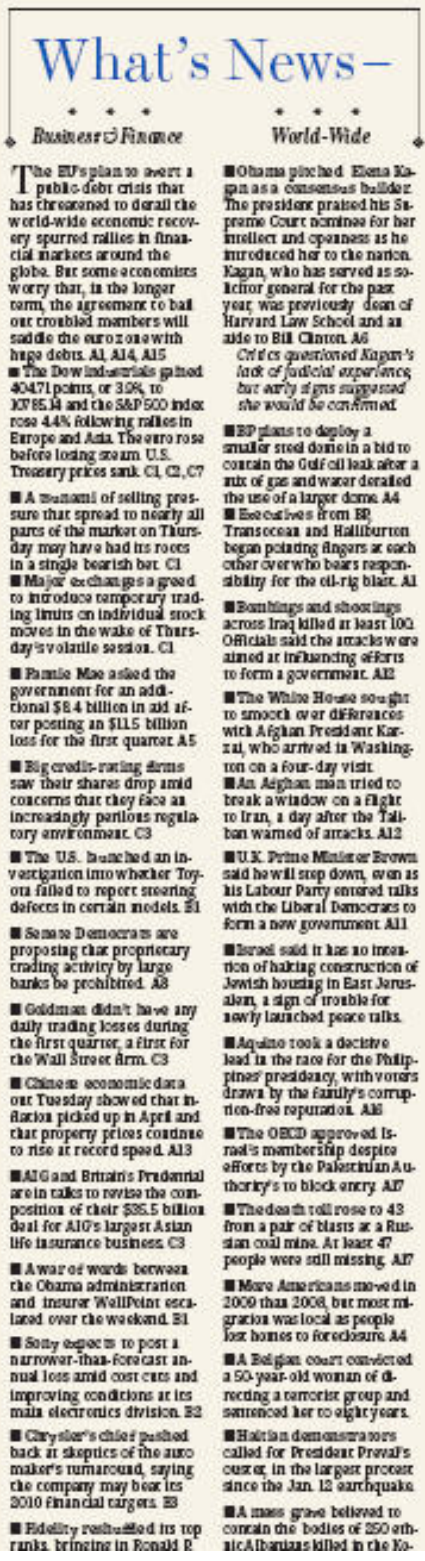

Europe Bailout Lifts Gloom

Stocks Surge on $\$ 955$ Billion Plan, but Economists Question Long-Term Burden

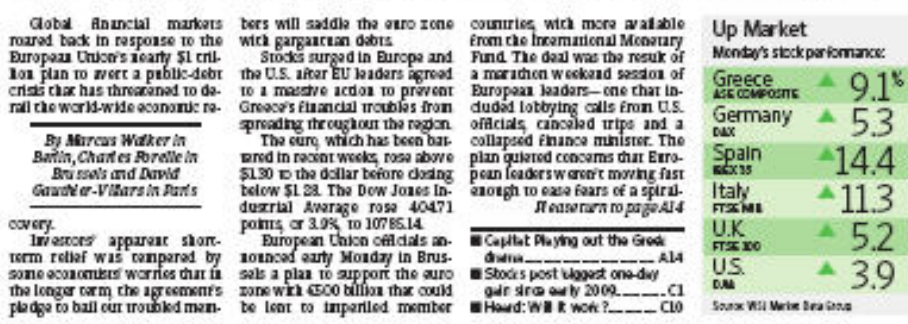

Court Nominee Comes to the Plate
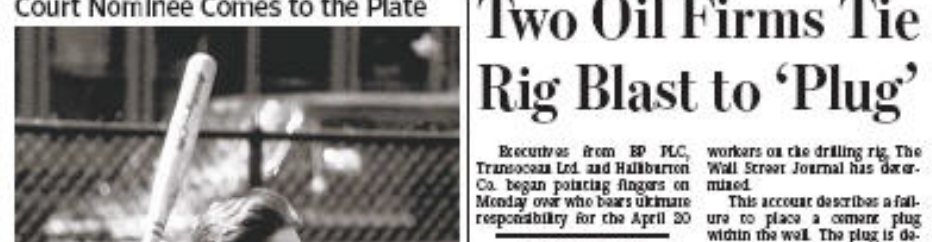

(1) (1)$$
\text { . }
$$
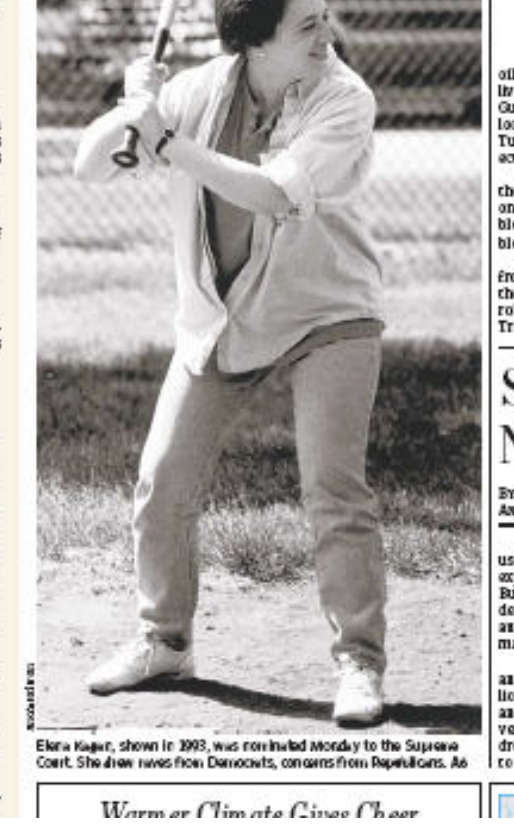

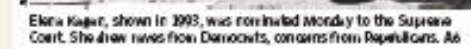

.

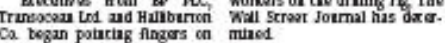

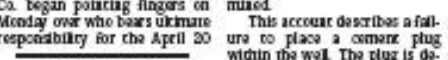
By Rassill cong

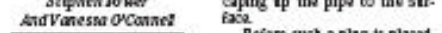

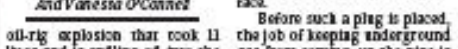

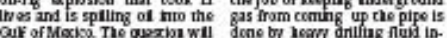

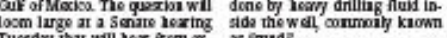

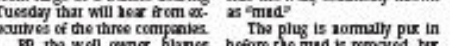

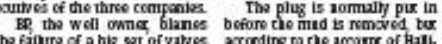

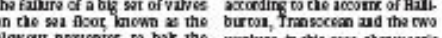

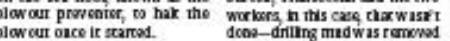
A differest axount cones before 2 find concent pluz was

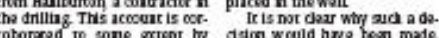

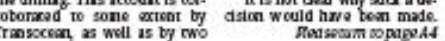
Strapped States Find New Virtues in 'Vice'

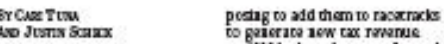

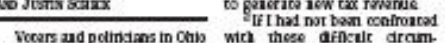

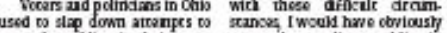

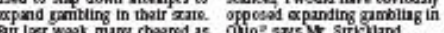

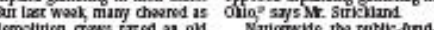

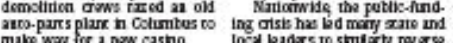

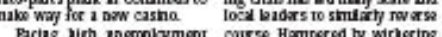

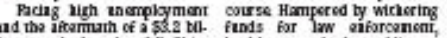

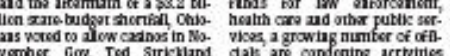

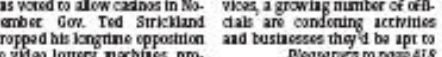
Wrrm er Clim ate flines Chear

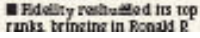

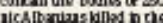

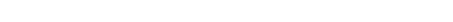




\section{Appendix C. Internet Search Results}

Accessed on April 23, 2011.

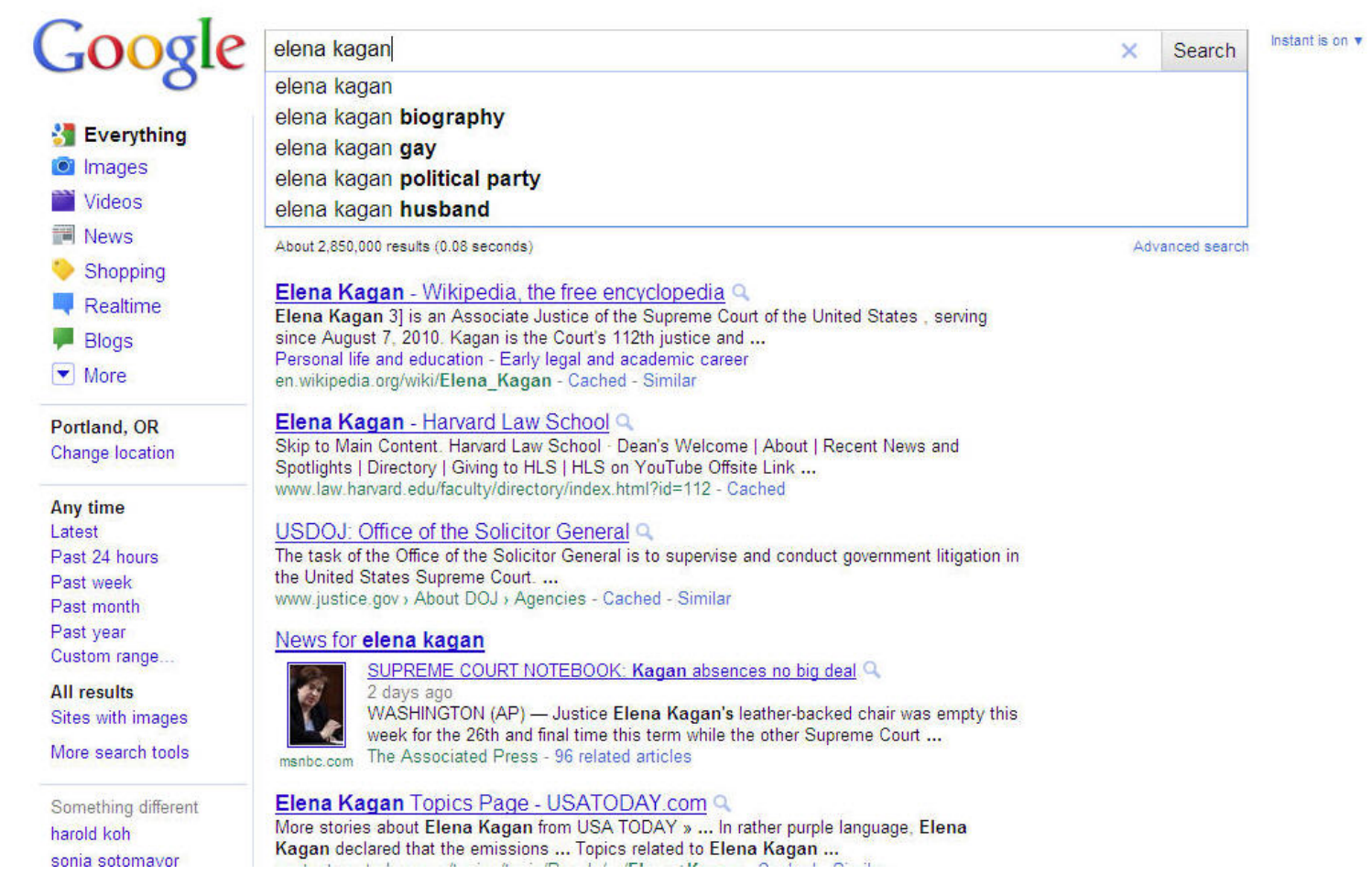




\section{Google}

8.1. Everything
Images
Videos
News
Shopping
Books
Blogs
More

Portland, OR Change location

Any time Latest Past 24 hours Past week Past month Past 2 months Past year Custom range.

All results Wonder wheel Related searches Timeline

More search tools sonia sotomayor|

sonia sotomayor sonia sotomayor biography

sonia sotomayor bio

sonia sotomayor quotes

sonia sotomayor cases

About $1,630,000$ results $(0.08$ seconds)

Sonia Sotomayor - Wikipedia, the free encrclopedia $Q$

Sonia Maria Sotomayor is an Associate Justice of the Supreme Court of the United States,

serving since August 2009. Sotomayor is the Court's 111th justice. ...

Early life - College and law school - Early legal career - Federal district judge

en wikipedia org/wiki/Sonia Sotomayor - Cached - Similar

Background on Judge Sonia Sotomayor | The White House 9

May 26, 2009 ... Sonia Sotomayor has served as a judge on the United States Court of Appeals for the Second Circuit since October 1998 ...

www. whitehouse gov/./Background-on-Judge-Sonia-Sotomayor/ - Cached - Similar

Images for sonia sotomayor - Report images

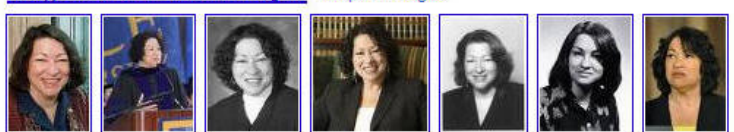

Sonia Sotomayor Supreme Court Nominee: All You Need To Know

May 1, 2009 ... President Barack Obama has tapped federal appeals judge Sonia Sotomayor for the Supreme Court, making her the first Hispanic in history ...

www. huffingtonpost.com/../sonia-sotomayor-supreme-c_n_194470.html - Cached - Similar

Who is Sonia Sotomayor? - CNN Q

May 26, 2009 ... Judge Sonia Sotomayor knew she wanted to go into law from an early age.As

a child, she aspired to be like Nancy Drew, the detective in the ...

\section{Google}

\section{Everything \\ [0] Images \\ Videos \\ News \\ Shopping \\ Realtime \\ - More}

Portland, OR

Change location

Any time

Latest

Past 24 hours

Past 2 days

Past week

Past month

Past year

Custom range

All results

Sites with images

More search tools

Something different

samuel alito

clarence thomas john roberts

john roberts

john roberts $\mathbf{c n n}$

john roberts fox

john roberts fox news

john roberts glass eights

About $2,150,000$ results $(0.14$ seconds)

Advanced search

John Roberts - Wikipedia, the free encrclopedia C

John Glover Roberts, Jr. (born January 27, 1955) is the 17th and current Chief Justice of the

United States. He has served since 2005 having been nominated...

Early years - Early legal career - On the DC Circuit

en wikipedia org/wiki/John_Roberts - Cached - Similar

John Roberts (journalist) - Wikipedia, the free encyclopedia $\mathrm{Q}$

John D. Roberts (born November 15, 1956) is an American television ...

en wikipedia. org/wiki/John_Roberts_(journalist) - Cached - Similar

† Show more results from wikipedia.org

Images for john roberts - Report images

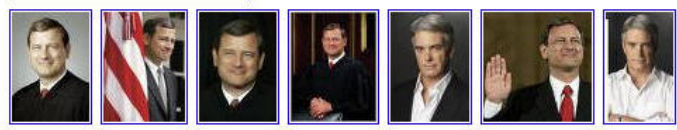

John Roberts Talks Fox News, Kyra Phillips \& Getting Awav From The ... Q

Feb 25, 2011 ... John Roberts doesn't miss the anchor desk. The former co-anchor of CNN's

American Morning." who recently jumped to Fox News, is now out on ...

www. huffingtonpost.com/...john-roberts-talks-fox-he n 828167 .html - Cached

\section{News for john roberts}

In VOPA v. Stewart: The Real Conservatism of Justice John Roberts $Q$ 


\section{Google}

\begin{tabular}{l} 
Everything \\
Shopping \\
Mores \\
Portland, OR \\
Change location \\
Any time \\
Latest \\
Past 24 hours \\
Past week \\
Past month \\
Past 3 months \\
Past year \\
Custom range... \\
All results \\
Sites with images \\
Wonder wheel \\
Timeline \\
More search tools \\
\hline Something different \\
clarence thomas \\
antonin scalia
\end{tabular}

\begin{tabular}{|l|l|}
\hline samuel alitol & $\times$ \\
\hline samuel alito \\
samuel alito biography \\
samuel alito westboro \\
samuel alito political party \\
samuel alito westboro dissent \\
\hline About 366,000 resuts $(0.10$ seconds) & \\
\hline
\end{tabular}

Samuel Alito - Wikipedia, the free encrclopedia $Q$

Samuel Anthony Alito. Jr is an Associate Justice of the Supreme Court of the United States.

He was nominated by President George W. Bush and has served on ...

Early life and education - Early legal career - Court of Appeals judge - Other activities

en wikipedia.org/wiki/Samuel_Alito - Cached - Similar

Samuel Alito - Supreme Court Justice - Biography

President Bush nominated Third Circuit Court of Appeals Judge Samuel Alito to replace Sandra

Day O'Connor. He was confirmed on 31 January 2006 and is the ...

uspolitics about.com/od/supremecourt/p/alito. htm - Cached - Similat

Justice Samuel Alito - Biography of Samuel Alito, Justice of the ... Q

A biography of Samuel Alito, Justice of the U.S. Supreme Court.

civilliberty about.com/od/./fig/./Justice-Samuel-Alito.htm - Cached - Similar

+ Show more results from about.com

Images for samuel alito - Report images

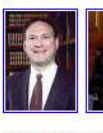

USNews.com: Nation and World: Samuel Alito Jr. (7/19/05) Q

Jul 19, 2005 ... Nicknamed "Scalito" for views resembling those of conservative Supreme Court

Justice Antonin Scalia, Samuel Alito Jr. is a favorite son of ...
Instant is on V

Ads

Related to supreme court justices

Supreme Court Justices

Read About Their Religious Beliefs www. momentmag com

Supreme Court Justices

Get Supreme Court Justices
Search for Supreme Court Justice

ask.com

See your ad here 